\title{
A TAXONOMIC SURVEY OF SEAWEEDS FROM ERITREA
}

\author{
M. ATEWEBERHAN ${ }^{1} \&$ W.F. PRUD'HOMME VAN REINE ${ }^{2}$
}

\author{
SUMMARY
}

\begin{abstract}
A survey of seaweeds was made in Eritrea in December 1995 and January 1996 on some islands of the Dahlak Archipelago and the surroundings of the port town of Massawa. During our study 101 specific and infraspecific taxa were identified, including 26 Chlorophyta, 20 Phaeophyta and 55 Rhodophyta. The survey resulted in 36 new records for Eritrea (11 Chlorophyta, 7 Phaeophyta and 18 Rhodophyta). Of these Eritrean records, 26 are new for the Red Sea (5 Chlorophyta, 4 Phaeophyta and 17 Rhodophyta). Comparison of records of seaweeds from localities in Eritrea to those from other localities in Eritrea as well as from other coasts of the western Indian Ocean have revealed that the regional distribution of seaweeds in the Red Sea is very patchy and that generally the area seems to be undersampled. The comparisons have also underscored the stressful seasonal environmental conditions for macroalgae in the southern Red Sea.
\end{abstract}

Key words: benthic marine macroalgae, biogeography, Eritrea, Red Sea, taxonomy.

\section{ERITREA AND ITS SEAWEEDS}

\section{INTRODUCTION}

\section{The environment}

The coastal zone of Eritrea lies in the southern part of the Red Sea and it is just over $1000 \mathrm{~km}$ long, excluding the Dahlak Archipelago. In older literature the coast of Eritrea is often named as the Ethiopian Red Sea coast. The maritime environment is controlled by the Indian Ocean monsoon system resulting in two distinct seasons: the cold season (north-eastern monsoon, October to April) and the hot season (south-western monsoon, May to September). Locally, winds blow to the north-west during the cold season and to the south-east in the hot season. Surface currents are in accordance with prevailing winds (Morcos, 1970). Lower water temperatures, greater water movement, higher nutrient levels and greater planktonic primary productivity are characteristic of the north-eastern monsoon. The parameters are reversed during the south-western monsoon (Morcos, 1970; Lipkin, 1987, 1991; Veldhuis et al., 1997). The water temperature in shallow reef areas fluctuates widely, with daily mean values of about $25^{\circ} \mathrm{C}$ in the cold season, $35^{\circ} \mathrm{C}$ in the hot season. In the cold season, these shallow reef areas become dominated by zone forming algae whose biomass decreases during the hot season (Ateweberhan, 2004).

1) Department of Marine Biology and Fisheries, University of Asmara, P.O. Box 1220, Asmara, Eritrea.

2) Nationaal Herbarium Nederland, Universiteit Leiden branch, Einsteinweg 2, P.O. Box 9514, 2300 RA Leiden, The Netherlands. 
The marine environment consists largely of soft substrate and shallow waters, with most areas within $50 \mathrm{~km}$ off the coast being less than $50 \mathrm{~m}$ deep. However, in some areas in the Dahlak Archipelago, the depth exceeds 200 m (Angelucci et al., 1982). The sediments and rocks are largely of fossil coral reef limestone extending over the entire range of the intertidal zone. In most places in Eritrea the tidal amplitude is rather small, with an average spring tidal range of less than a metre. Horizontal platforms of fossil reef limestone formed by abrasion are common. Some of these are highly sheltered and lined at intertidal levels by convex or vertical walls. Cliffs, caves and boulders of eroded fossil limestone occur at higher intertidal levels along shores with strong wave action. In places of where a dry river (wadi) reaches the coast, these rocky limestone substrates are interrupted by terrigenous sediments or sandy covers (Lipkin, 1987, 1991).

\section{Phycological exploration}

Exploration of the Red Sea dates back as far as the 18th century. The first record of algae from the Red Sea was published by Strand (a student of Linnaeus) in 1756 (Papenfuss, 1968a). However, the first major algal collection was made by Forsskål (1775) during his journey to Egypt and Arabia. He described some new species from the region. Forsskål's specimens, which are in Copenhagen, were examined by many botanists and were revised by Børgesen in 1932. The first records of algae from Eritrea came from Ehrenberg \& Hemprich who visited the Dahlak Archipelago during their six-year trip (1820-1826) to Egypt, Arabia and the western coasts of the Red Sea, including Eritrea. Hemprich died in Massawa, Eritrea. Ehrenberg did most of his work on corals but described two algal species including the famous Trichodesmium erythraeum, whose bloom is said to contribute to the colour of the Sea and hence the name (Papenfuss, 1968a; Lipkin, 1991).

In the 19th century, a number of botanists, mostly Germans and Italians, visited the region and a brief history has been given by Papenfuss (1968a). Zanardini (1851) published on algae collected from the Dahlak Archipelago and Massawa and other parts of the Red Sea, describing 23 new species and a new genus (Portieria). Other new species of algae and a new genus (Sarconema) were described by him in another account on the Red Sea (Zanardini, 1858). Piccone (1884, 1886, 1889, 1893, 1900a, b, c) published seven papers dealing completely or in part with the Red Sea. Many of his new species were co-authored by A. Grunow. Especially many Sargassum taxa were described at lower taxon levels, see also Grunow (1915-1916). Licata (1882) published on the algae collected from the Assab area and De Toni \& Paoletti (1888) made an account of 31 species from the region.

This early stage of phycological exploration was characterized by the collection of specimens and their taxonomic and floristic treatment by Europeans, to whom little or no ecological information was available (Lipkin, 1991). The modern scientific history of the Red Sea begins with the establishment of marine research stations at Ghardaqa (Hurgada), Egypt in the 1930s and in Israel in 1968. Rayss (1959) and Rayss \& Dor (1963) have added to the knowledge of the algae of the Sinai Peninsula and the Gulf of Aqaba. While marine stations were being established in the northern part of the Red Sea, the southern part remained largely unknown. Records of algae in the southern Red Sea are very scattered in literature and are based mostly on short period collections of 
the 20th century. Intensive collecting was carried out by the 1962 and 1965 Israel South Red Sea Expeditions, but in a limited area. Papenfuss (1968a) compiled a catalogue of previously published records of Red Sea algae, totalling 493 specific and infraspecific taxa, of which 116 (24\%) were in the genus Sargassum. Collections from the Israeli expeditions were the bases of reports on Turbinaria (Taylor, 1964), Caulerpa (Taylor, 1967), Chlorodesmis (Ducker, 1967, 1969), Cystophyllum and Cystoseira (Papenfuss \& Jensen, 1967), Hormophysa (Papenfuss, 1968b), Leveillea (Scagel \& Chihara, 1968) and Sarconema (Papenfuss \& Edelstein, 1974). Lipkin (1987) reported on the intertidal distribution of benthic marine macroalgae from Entedebir and Museri islands. An overall account of the collections made by the Israeli expeditions was only recently published (Lipkin \& Silva, 2002). This account treats 127 specific and infraspecific seaweed taxa representing 73 genera. Among these algae, 13 genera and 47 species had not been recorded previously from the Red Sea. The collections came mainly from the Entedebir and Museri islands, which were the base camps of the 1962 and 1965 expeditions, respectively. Different habitats were visited within the two localities and considerable amount of time spent in field observation and collection. Most of the ecological and biogeographic suggestions about benthic algae in the southern part of the Red Sea still are biased by interpretations of patterns observed in the northern Red Sea (Walker, 1987).

\section{Seaweed distribution and biogeography of the Red Sea flora}

The Red Sea, which was, in the Miocene, a southern extension of the Mediterranean Sea, was disconnected from it geologically recently (Head, 1987). It is properly regarded as a continuation of the Indian Ocean Ridge and, effectively, a nascent ocean (Braithwaite, 1987). The origin of the fauna and flora of the Sea is essentially from the Indian Ocean, migration from and to the Mediterranean being possible only after the opening of the Suez Canal (Lipkin, 1972, 1991). The southern Red Sea, with its high salinity and warm water extending to the bottom, is oceanographically unique. The mean sea surface temperature in August is over $32{ }^{\circ} \mathrm{C}$ in the southern part of the Red Sea, and it is always c. $21.5^{\circ} \mathrm{C}$ in the deeper parts (Edwards, 1987; Ateweberhan, 2004). Temperatures of $36-38^{\circ} \mathrm{C}$ are very probable in the extensive shallow waters in the southern part of the Red Sea in mid summer and, in the lagoons behind the fringing reefs, readings of up to at least $45^{\circ} \mathrm{C}$ have been recorded (Edwards, 1987). In Eritrea Ateweberhan (2004) reports seawater temperatures of over $36^{\circ} \mathrm{C}$ in the Sargassum zone in the shallow reef flat. Average salinity in the southern Red Sea is 38 ppt, with intermittent occurrence of higher (39 ppt) or lower (36.5 ppt) values (Edwards, 1987). In the deeper parts salinity is always around $40.5 \mathrm{ppt}$ (Ateweberhan, 2004). Reflecting its isolation from the Indian Ocean until about 15-20 thousand years ago, the Red Sea supports a relatively high level of endemism, including $9 \%$ for macroalgae. Proving endemism, however, requires extensive comparative collections (Head, 1987), as sound taxonomic work is a precondition for all types of biogeographical studies. Differences in physical parameters of the various parts of the Red Sea are also paralleled by differences in the biota occurring in the different regions. Species diversity increases from north to south and a marked difference in species composition can be observed along the coast extending from the northern Red Sea through the Gulf of Aden into the western Indian Ocean. The algal genera Caloglossa and Chlorodesmis and the species 
Caulerpella ambigua, Caulerpa fastigiata and C. selago are restricted to the southern part of the Red Sea (Lipkin, 1991). Many Red Sea seaweed species have a cosmopolitan distribution. Some taxa are reported to be endemic to the Red Sea, whereas others are found in particular localities in the Red Sea and also in the Indo-West Pacific. However, the coasts in the southern and central parts of the Red Sea, especially those of Saudi Arabia, are poorly known (Head, 1987; Lipkin, 1991).

Geological events have clearly been of major importance for the formation of disjunct distribution patterns of seaweeds. An originally continuous distribution range may be split in two disjunct regions due to tectonic or paleoclimatic events (vicariance). On the other hand, disjunct distributions may also be the result of dispersal, which involves the crossing of barriers and colonization of new areas (Pakker, 1995). Historical biogeographic approaches, such as cladistic biogeography are rapidly developing, but application of such an approach in a Red Sea/Indian Ocean context requires solid taxonomic information.

\section{DISCUSSION}

A total of 286 specific and infraspecific taxa of seaweeds have been recorded for the coast of Eritrea. These have been collected by different people in different seasons and in different habitats. Records do not necessarily come from specialists and errors in identification and nomenclature might occur; moreover, old records might not give the present interpretation of the taxa. To the 44 specific and infraspecific taxa newly recorded by Lipkin \& Silva (2002), we add another 36 (Table 1). Considering the high number of newly recorded taxa, the conclusion by Lipkin \& Silva (2002) that the knowledge of the marine flora of the Red Sea was far from complete can thus be endorsed by our results.

Table 1. Number of specific and infraspecific taxa of macroalgae reported from Eritrea.

\begin{tabular}{lcccc}
\hline Taxon & Chlorophyta & Phaeophyta & Rhodophyta & Total \\
\hline previous + present records & 50 & 108 & 128 & 286 \\
present report & 26 & 20 & 55 & 101 \\
new records therein & 11 & 7 & 18 & 36 \\
\hline
\end{tabular}

Lipkin \& Silva (2002) also discussed the influence of the seasons, without reaching a clear conclusion. Our samples were collected in winter, which might be the reason for the difference when compared with the samples recorded by Lipkin \& Silva (2002), which were collected in spring and autumn. Localities near Massawa and in the Dahlak Archipelago experience extreme seasonality in environmental parameters. Macroalgal species diversity, productivity and biomass are highest in the cold season from December to April and lowest in the hot season from July to September (Ateweberhan, 2004). Brown algae, such as Colpomenia sinuosa, Hydroclathrus clathratus and Rosenvingea intricata, were reported only from the outer islands in the Dahlak Archipelago and near Assab, and only during the cold season (Ateweberhan, unpublished results). They also grow in winter in northern Red Sea localities but have never been recorded in the inner 
waters of Massawa and the Dahlak Archipelago, even during the coldest months. In both cold and hot seasons, northern Red Sea localities experience lower water temperatures than localities in the southern Red Sea.

The number of recorded taxa is also influenced considerably by patchy distribution patterns. Of the 101 specific and infraspecific taxa recorded in the present study, 20 have been found only on the mainland coast, while 55 taxa were found only on one island, 15 on two islands and 11 on three islands. However, results of a survey like the present one or that by Lipkin \& Silva (2002) are not fully suitable for comparison with earlier data or with each other, because of differing taxonomic opinions and the patchy distribution patterns in the southern part of the Red Sea. If we compare separate islands, for example, we see that on Nokra Island 38 taxa were recorded. Of these, 35 were reported by us, 6 by Lipkin \& Silva (2002) and only 3 by both surveys. For Sheik Said Island only two of the 41 taxa reported in the present study were recorded by Lipkin \& Silva (2002). For Dur-gam Island, where the Israeli expeditions did not collect, we recorded 40 taxa. In a separate analysis of the 79 specific and infraspecific taxa that were recorded from these three islands during the two surveys, 54 taxa were found on one island only. For 12 taxa, records from two islands are available and only 13 taxa were recorded from all three islands. This again illustrates the marked differences between the islands and thus the patchy distribution of the seaweed taxa. Islands that are very close to each other, have surprisingly large differences in species composition. This is also the case with other coral reef communities of some islands in the Dahlak Archipelago and other localities (Ateweberhan, pers. obs.). Although species richness generally reflects variation in physical factors of the environment, many comparisons of similar environments in different parts of the world have revealed different numbers of species (diversity anomalies). What appear to be similar habitats may, in fact, differ in fundamental attributes affecting species richness. Differences in local species richness might arise from the particular history and biogeographical circumstances of each region, quite apart from the contemporary local environment (Schils \& Coppejans, 2003).

We have listed all previously recorded species that we did not collect ourselves together with relevant distributional data (not shown). To our surprise, some species that are supposed to be ubiquitous in the region are not reported for the Eritrean coast. It is not possible, within the short period of sampling, to find all species of marine macroalgae that have been recorded in the literature as being present in the area. Even in the present report, some rare taxa are reported while others, supposedly common, are missing

Difficulties were encountered in identifying several species of the brown algal genera Dictyota and Sargassum as well as in the red algal genera Champia, Chondria, Gelidium, Gracilaria, Hypnea and Pterocladiella. We did not try to include non-geniculate coralline red algae in our samples because methods for collecting and for detailed study are different from the methods used in the study of other benthic macroalgae. In the limited time available for fieldwork we could not incorporate these deviating studies. We did not include blue-green algae (cyanobacteria), although several of these organisms ecologically have much in common with marine macroalgae. Lipkin \& Silva (2002) included five species of cyanobacteria as well as four species of seagrasses (Anthophyta) 
in their paper, but also did not include non-geniculate coralline algae. The first author of the present paper has made extensive collections between 1997 and 2001 in localities near Massawa, the Dahlak Archipelago and the Hawakil and Assab areas. As part of his investigation of turf algal species composition and biomass, he then included blue-green algae as well (Ateweberhan, 2004). The number of new records for Eritrea and the Red Sea can be expected to rise again in the future.

It can be stated that all comparative studies of numbers of specific and infraspecific seaweed taxa occurring in the southern Red Sea are biased as a result of the numerous taxa described in Sargassum by Grunow (1915-1916). Sargassum poses many taxonomic difficulties due to its high morphological variability which is caused by the position of leaves and vesicles on the plant (basal or apical), sexual dimorphism, ontogeny, seasonality, environmental factors, random phenotypic expression and geographically correlated genotypic differences (Kilar et al., 1992; Silva et al., 1996). Out of the 108 taxa of Phaeophyta recorded for Eritrea, 71 belong to Sargassum (in 36 species). For the Massawa area alone, previously 18 species of Sargassum were recorded; whereas in the present survey we could only identify three species, of which one is new for the area. Lipkin \& Silva (2002), however, recorded 9 taxa, belonging to 8 species, of which one was also found by us. Of these nine Sargassum taxa recorded by Lipkin \& Silva, however, only 4 were growing attached, all others were drift material. Drift material is not included in the present report.

Table 2. Regional distribution (in numbers) of specific and subspecific taxa of macroalgae reported from Eritrea and also found in other areas. Codes: Eritrea: from Eritrean coasts. Red Sea: from the Red Sea coasts, excl. Eritrea. NWIO: from the north-western part of the western Indian Ocean. SWIO: from the south-western part of the western Indian Ocean. Arabian Gulf: from the Arabian Gulf.

\begin{tabular}{lccccc}
\hline Taxon & Eritrea & Red Sea & NWIO & SWIO & Arabian Gulf \\
\hline Chlorophyta & 50 & 37 & 45 & 44 & 18 \\
Phaeophyta & 108 & 47 & 45 & 32 & 30 \\
Rhodophyta & 128 & 65 & 87 & 77 & 35 \\
\hline
\end{tabular}

Table 2 shows the regional distribution of the macroalgae occurring in Eritrea that are also reported in the available references as occurring in neighbouring areas. See for the relevant titles the ones marked with $*$ in the list of references. In determining the regional distribution, even single records for one country or locality are considered to be representative for a whole region. This is because information is very scarce and the gaps in the distribution records are wide. For the Red Sea region (which here includes all Red Sea coasts except Eritrea), Egypt has the highest numbers of records of the taxa that are also reported from Eritrea. For the western Indian Ocean the north-western subarea (the coasts of Africa extending from Tanzania to the Gulf of Aden coast of Djibouti, together with the Seychelles and Socotra as well as the Gulf of Aden coast of Yemen and the Indian Ocean/Arabian Sea coasts of the Arabian Peninsula and the Gulf of Oman) has the highest number of these taxa. This probably mainly reflects the amount of work done in the above mentioned places with respect to macroalgae in the 
last few decades and it does not necessarily mean that these coasts (of Egypt and the north-western part of the Indian Ocean) are biogeographically closely related to the Eritrean coast. To make comparisons more meaningful, more ecological and taxonomic work on a regional basis is required.

\section{ACKNOWLEDGEMENTS}

The first author would like to thank the Fundamental and Applied Marine Ecology (FAME) staff of the Free University of Brussels, Prof. P. Polk, Prof. N. Daro, Dr. M. Tackx and others, for their academic assistance during his stay in the programme. We are grateful to the staff of the Nationaal Herbarium Nederland, Universiteit Leiden branch, for their cooperation. The costs of transportation and field work in Eritrea were covered by FAME, ABOS (Belgian Overseas Development) and by the Prof. Lam Fund of the Nationaal Herbarium Nederland, Universiteit Leiden branch. We especially thank the staff of the Department of Marine Biology and Fisheries, University of Asmara and the Research Unit of the Ministry of Fisheries, Eritrea (Mrs. Sahlu Ghebregziabher, in particular) for their help and cooperation during field study in Eritrea. The authors thank Prof. E. Coppejans (who was copromoter for the first author) for the helpful comments. The present paper, based on the MSc thesis of the first author, had to be rewritten when it became clear that another paper (Lipkin \& Silva, 2002) was more or less on the same topic. The authors thank Dr. P.C. Silva and Dr. R.L. Moe for making the manuscript of the Lipkin \& Silva paper available for consultation before its publication.

\section{THE SURVEY}

\section{MATERIALS AND METHODS}

\section{The study area}

A survey of the seaweeds was executed in Eritrea in December 1995 and January 1996 (Fig. 1). A general collection of benthic marine macroalgae was made in the vicinities of the port town of Massawa (Mitsi'wa) viz. near the Marine Station $\left(15^{\circ}\right.$ $36^{\prime} \mathrm{N}, 39^{\circ} 28^{\prime} \mathrm{E}$ ) and at nearby Resi Medri (15 $37^{\prime} \mathrm{N}, 39^{\circ} 28^{\prime} \mathrm{E}$ ), at Hirghigo (Bay of Archico, $\left.15^{\circ} 32^{\prime} \mathrm{N}, 39^{\circ} 30^{\prime} \mathrm{E}\right)$, Gurgussum Beach (Massawa) $\left(15^{\circ} 40^{\prime} \mathrm{N}, 39^{\circ} 25^{\prime} \mathrm{E}\right)$ and at Sheik Said Island $\left(15^{\circ} 35^{\prime} \mathrm{N}, 39^{\circ} 29^{\prime} \mathrm{E}\right)$. Other collections were made on some of the inner islands in the Dahlak Archipelago, namely: Dur-gam Island $\left(15^{\circ} 47^{\prime} \mathrm{N}\right.$, $\left.39^{\circ} 45^{\prime} \mathrm{E}\right)$, Dur-gella Island $\left(15^{\circ} 43^{\prime} \mathrm{N}, 39^{\circ} 47^{\prime} \mathrm{E}\right)$, Nokra Island $\left(15^{\circ} 43^{\prime} \mathrm{N}, 39^{\circ} 56^{\prime} \mathrm{E}\right)$ and Dissei Island $\left(15^{\circ} 27^{\prime} \mathrm{N}, 39^{\circ} 45^{\prime} \mathrm{E}\right)$, a continental island on the northern tip of the Buri Peninsula. This was the basis for the MSc thesis of the first author (Ateweberhan, 1996). Occasionally additional material is added, which was collected by Ateweberhan in winter 2000 and 2002 (some from Tewalet, at Massawa, $15^{\circ} 36^{\prime} \mathrm{N}, 39^{\circ} 27^{\prime} \mathrm{E}$ ).

\section{Collection and identification}

Seaweeds were collected by wading along the shores and by free-diving down to $6 \mathrm{~m}$. Plants were collected by hand or detached with a knife. Notes of specimens, habitats, occurrence, substrate, sediment type, etc. were taken. A preliminary identification of collected plants was made on the spot. In the laboratory, further identification was carried out, herbarium material was prepared and some specimens were preserved in $4 \%$ formalin in seawater. Herbarium material and preserved plants were transported 


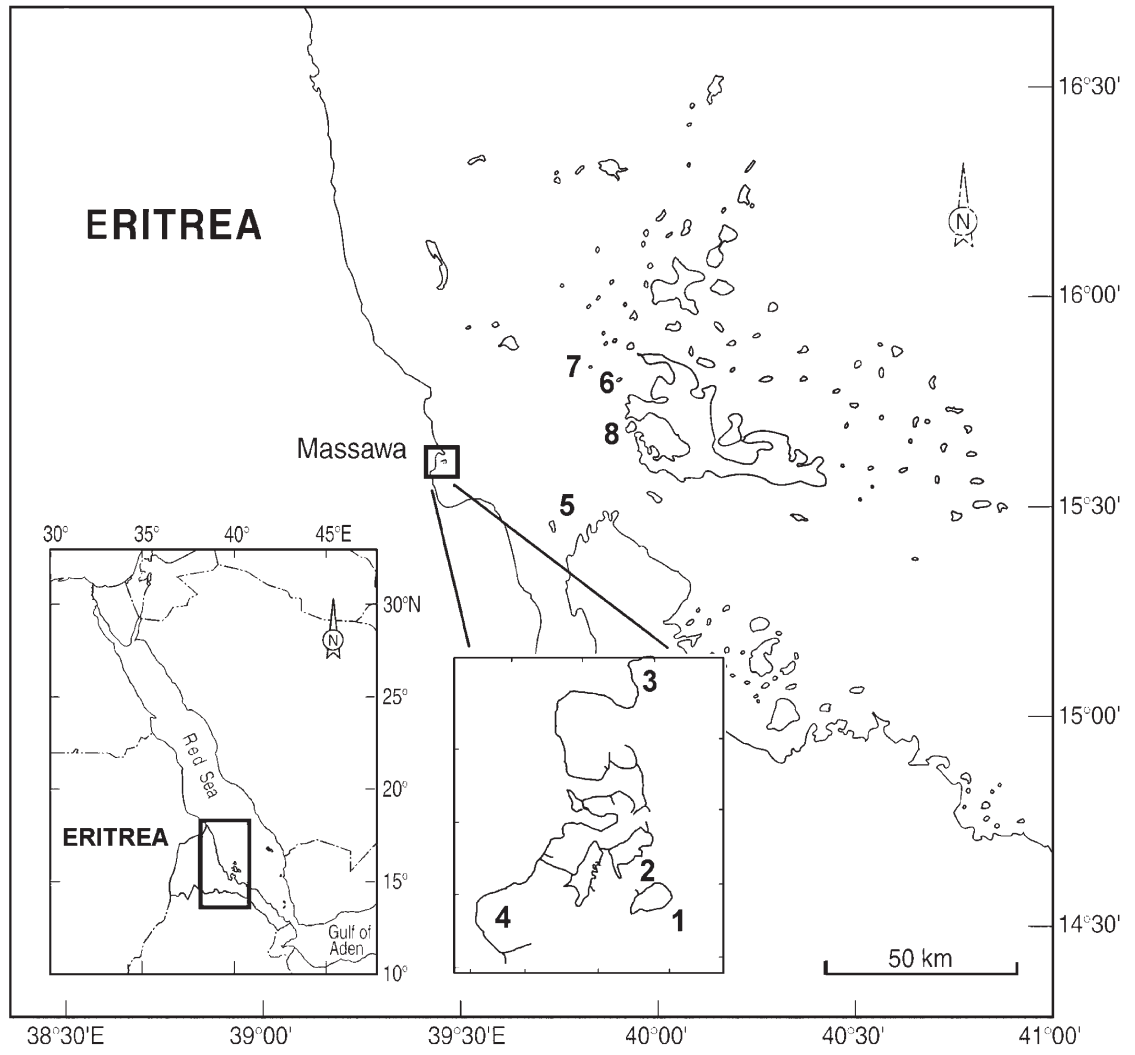

Fig. 1. The study area on the Eritrean Red Sea Coast. Localities in and around Massawa: 1. Sheik Said Island; 2. Resi Medri (Marine Station); 3. Gurgussum; 4. Hirghigo. Localities in the Dahlak Archipelago: 5. Dissei Island (continental island close to the mainland coast); 6. Dur-gam Island; 7. Dur-gella Island; 8. Nokra Island.

to the Netherlands for further identification at the Nationaal Herbarium Nederland, Universiteit Leiden branch, where many of the specimens are now deposited.

The identifications in this survey were mainly based on publications by Børgesen (1940-1957), Taylor (1960), Jaasund (1976), Lawson \& John (1987) and comparisons with the papers by Papenfuss (1968a) and by Lipkin \& Silva (2002). Regional distribution was mainly based on Papenfuss (1968a) and Farghaly (1980), while records for the Indian Ocean, as well as for recent nomenclature are mainly based on Silva et al. (1996). Other publications from the western Indian Ocean region and the Red Sea, mainly those that have been published after publication of the papers by Papenfuss (1968a) and by Farghaly (1980), were also consulted. Our identifications were based on morphological and easily determined structural and reproductive characters. Cross sections were made either by hand or with a freezing microtome. A light microscope was used to aid visual identification. Whenever necessary, collected specimens were compared to herbarium material at the Nationaal Herbarium Nederland, Universiteit Leiden branch. Data on non-geniculate coralline algae, blue-greens and endolithic algae 
were not included. Distribution records for Eritrea are given by collection sites and by reference to recent papers. The paper by Lipkin \& Silva (2002) covers algae collected from several islands in the Dahlak Archipelago. When the collectors visited the same island as we did, reference to such an island is included in our distribution data. For other localities we refer to their paper (Lipkin \& Silva, 2002). Records of specific and infraspecific seaweed taxa from Eritrea were compared to the rest of the Red Sea and to the western Indian Ocean subregions. Distribution within the Red Sea is given by country, viz. Sudan, Egypt, Jordan, Israel, Saudi-Arabia and Yemen and for the rest of the coasts of the western Indian Ocean by regions. The south-western Indian Ocean (SWIO) subregion includes the coasts of South Africa to Mozambique, together with the Comoro Islands, Réunion, Mauritius, and Madagascar. The north-western (NWIO) subregion of the Indian Ocean includes the coasts of Africa extending from Tanzania to the Gulf of Aden coast of Djibouti, together with the Seychelles and Socotra as well as the Gulf of Aden coast of Yemen and the Indian Ocean/Arabian Sea coasts of the Arabian Peninsula and the Gulf of Oman. The third major subregion of the western Indian Ocean is the Arabian Gulf.

\section{RESULTS \\ IDENTIFICATION KEYS OF THE SEAWEEDS FROM ERITREA FOUND DURING THE PRESENT STUDY}

The taxonomic system as used by Silva et al. (1996) is followed in the present report, although we have used the ending - phyta and not -phyceae. Within each order the genera and species are arranged in an alphabetical sequence. Data for each taxon include: the accepted name and author (cited in accordance with Brummitt \& Powell, 1992, with the correction of 'Grunov' to Grunow), synonyms often used in literature on Red Sea algae, references where descriptions of the algae can be found, the site of collection and records from earlier workers and/or by us, to which are added data from Lipkin (1987) and Lipkin \& Silva (2002). These are followed by data on the general distribution in the Red Sea and the western Indian Ocean and finally our collection number(s). Taxa newly recorded for Eritrea are indicated by an asterisk (*) and those new for the Red Sea in general by two asterisks (**).

Identification keys in this paper cover only the species recorded by us.

\section{RHODOPHYTA}

\section{KEY TO THE GENERA OF RHODOPHYTA FROM ERITREA}

1a. Plants calcified; thallus distinctly segmented $\ldots \ldots \ldots \ldots \ldots \ldots \ldots$ Jania

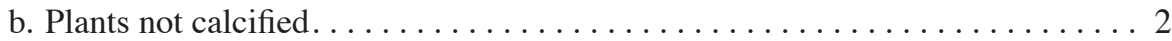

2a. Thallus completely or in part hollow or filled with mucilage $\ldots \ldots \ldots \ldots . \ldots 3$

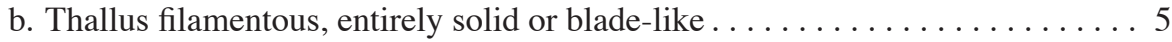

3a. Thallus consisting of solid, terete, branched axes bearing a number of vesicles ..

b. Thallus not so differentiated $\ldots \ldots \ldots \ldots \ldots \ldots \ldots \ldots \ldots \ldots$ 
4a. Thallus hollow; branches slightly constricted and a transverse septum at each constriction; segments cylindrical to barrel shaped............ Champia

b. Thallus hollow, not constricted, septa absent. . . . . . . . Coelothrix

5a. Thallus membranous or somewhat flattened, partly monostromatic . . . . . 6

b. Thallus filamentous, terete or compressed, but never monostromatic . . . . . 8

6a. Thallus with net- or grid-like structures. . . . . . . . . Martensia

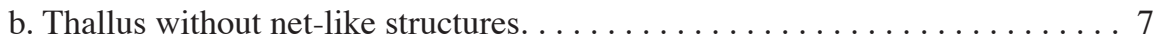

7a. Thallus with a conspicuous midrib of elongated cells . . . . . . Caloglossa

b. Polysiphonous axes bearing two rows of leaf-like branches . . . . . . Leveillea

8a. Axes wide (in general more than $3 \mathrm{~mm}$ wide) . . . . . . . . . . . . 9

b. Axes narrow (in general less than 3 mm wide) . . . . . . . . . . . . . . 10

9a. Medulla pseudoparenchymatous . . . . . . . . . . . . Gracilaria

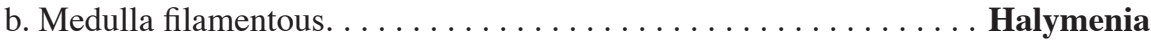

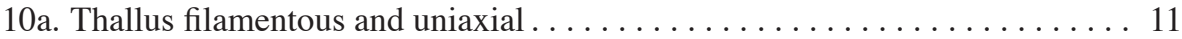

b. Thallus terete or compressed, polyaxial, solid and (pseudo)parenchymatous. 21

11a. Thallus strictly monosiphonous and uniseriate . . . . . . Colaconema

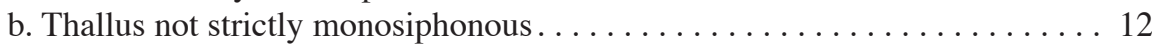

12a. Periaxial cells shorter than central cells, giving rise to complete or incomplete

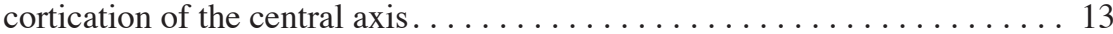

b. Periaxial cells as long as the central cells . . . . . . . . . . . . . 15

13a. Cortication restricted to the nodes of the axial filament ....... Ceramium

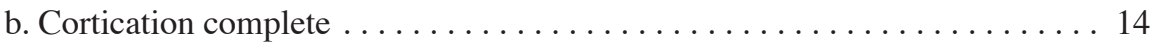

14a. Growth monopodial, tips with a single apical cell. . . . . . . . Corallophila

b. Branching dichotomous, branch tips forked, with whorls of 1-3 celled spines . .

Centroceras

15a. Axes bearing radially arranged monosiphonous branchlets . . . . . . . Dasya

b. No monosiphonous branchlets on axes . . . . . . . . . . . . . 16

16a. Thallus bearing spine-like branchlets . . . . . . . . . Acanthophora

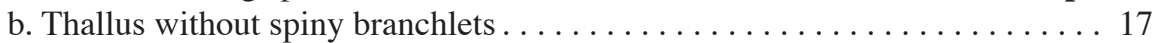

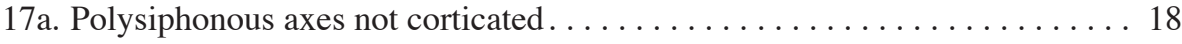

b. Polysiphonous axes corticated . . . . . . . . . . . . . . . . . . 19

18a. Branches bearing a characteristic sequence of simple and compound branches. .

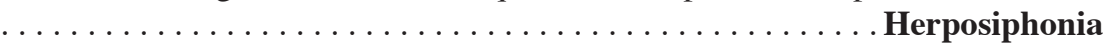

b. Branches with no such a characteristic sequence. . . . . . . . Polysiphonia

19a. Terminal branches constricted or tapered at the base . . . . . . . . Chondria

b. Terminal branches obtuse, not constricted or tapered at the base . . . . . . 20

20a. With four pericentral cells per central cell; both 'corps en cerise' and epidermal secondary pit connections present . . . . . . . . . . . Laurencia

b. With two pericentral cells per central cell; both 'corps en cerise' and epidermal

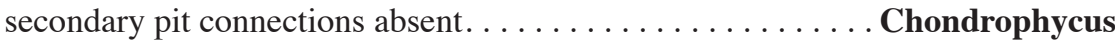

21a. Medulla filamentous. . . . . . . . . . . . . . . . . . Sarconema

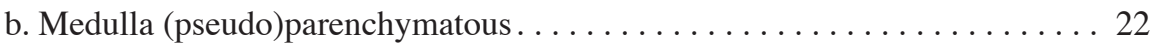

22a. Thallus rather soft, fleshy or somewhat stiff $\ldots \ldots \ldots \ldots \ldots \ldots \ldots \ldots$

b. Thallus markedly cartilaginous or leathery . . . . . . . . . . . . 24

23a. Thallus prostrate or erect, often bushy with many radially arranged branches; medullary area narrow and with few cells only ............ Hypnea 
b. Plants not so bushy; not profusely branched; medullary area broad and with many

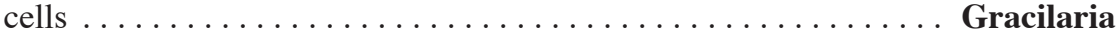

24a. Plants with internal rhizines. . . . . . . . . . . . . . . . 25

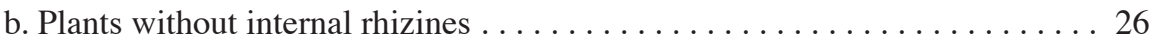

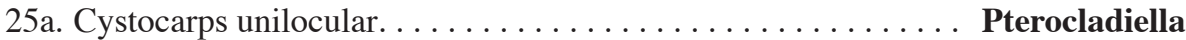

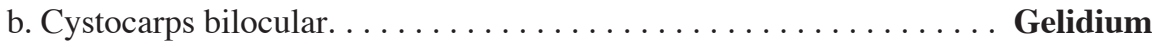

26a. Branch tip with a single apical cell . . . . . . . . . . . . Gelidiella

b. Branch tip without a prominent apical cell . . . . . . . . . . . 27

27a. Thallus small (about $2 \mathrm{~cm}$ ), cells in section uniform........ Wurdemannia

b. Thallus irregularly branched, 5-7 $\mathrm{cm}$ high, central cells small and thick walled

Gelidiopsis

\section{ACROCHAETIALES}

\section{COLACONEMA Batters}

Colaconema gracile (Børgesen) Ateweberhan \& Prud'homme, comb. nov.

Basionym: Acrochaetium gracile Børgesen in Dansk Botanisk Archiv 3 (1915) p. 26-27, f. 19 \& 20.

Audouinella gracilis (Børgesen) Jaasund

Literature - Jaasund, 1976; Silva et al., 1996.

Distribution - Eritrea: Gurgussum, Sheik Said Island; Dahlak Archipelago (Lipkin \& Silva, 2002). Western Indian Ocean: NWIO.

Note - The thallus is composed of uniseriate and branched filaments. Erect filaments arise from small basal discs. Branching is usually scarce and lateral, tending to be second towards the apex. Cells with a single parietal chloroplast with a large single pyrenoid. Plants are epiphytic on Acanthophora spicifera, Padina spp. and Sargassum spp. This species clearly belongs to the genus Colaconema, hence the proposed new combination.

Specimen studied: ER-RH-154.

\section{GELIDIALES}

\section{GELIDIELLA Feldmann \& Hamel}

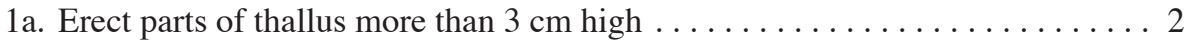

b. Erect parts less than $3 \mathrm{~cm}$ high $\ldots \ldots \ldots \ldots \ldots \ldots \ldots \ldots \ldots \ldots \ldots \ldots \ldots \ldots \ldots$

2a. Thallus more or less cylindrical throughout, densely branched, diameter of main axes about $0.5 \mathrm{~mm} \ldots \ldots \ldots \ldots \ldots \ldots \ldots \ldots \ldots \ldots \ldots \ldots \ldots \ldots$ Gelidiella spec.

b. Thallus cylindrical only in proximal parts, distal parts compressed, straight or curved abaxially, main axes about $1 \mathrm{~mm}$ diameter . . . . . . . . G. acerosa

3a. Thallus forming dense mats, bi- or tripinnately branched, usually $1 \mathrm{~cm}$ high ... $\ldots \ldots \ldots \ldots \ldots \ldots \ldots \ldots \ldots \ldots \ldots \ldots \ldots \ldots \ldots \ldots$. myrioclada

b. Thallus less than $1 \mathrm{~cm}$ high, erect part less branched $\ldots \ldots \ldots \ldots$ G. Iubrica 


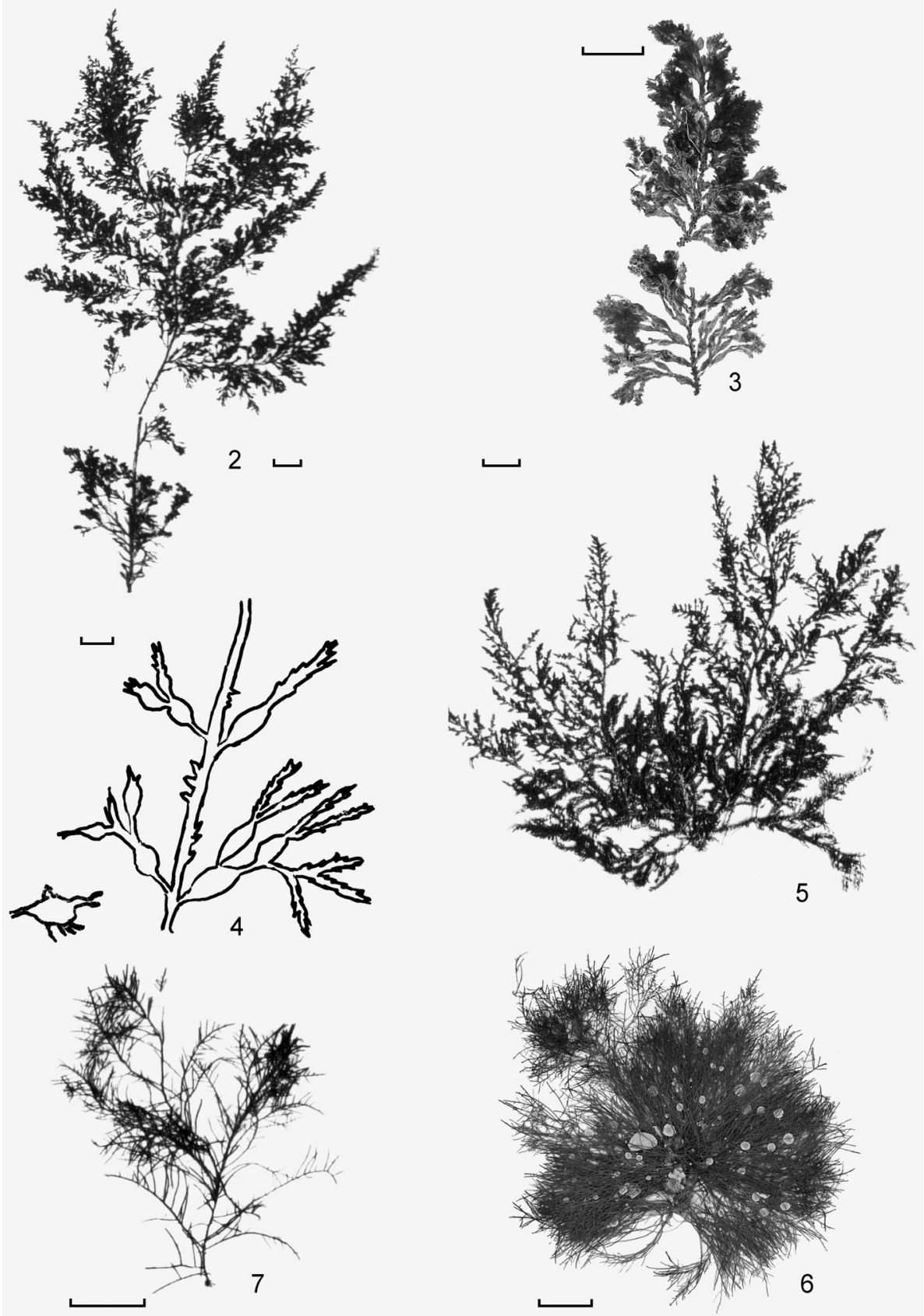

Fig. 2-7. - 2-4. Cystoseira spec.: plant with intercalary vesicles, habits. - 5. Cystoseira myrica: habit. $-6,7$. Gelidiella spec.: habit. - Scale bars: $2,3,5=10 \mathrm{~mm} ; 4=1 \mathrm{~mm} ; 6=5 \mathrm{~mm} ; 7=6 \mathrm{~mm}$. 
Gelidiella acerosa (Forssk.) Feldmann \& Hamel

Literature - Jaasund, 1976; Hatta \& Prud'homme van Reine, 1991.

Distribution - Eritrea: Assab Archipelago, Mandola Island, Massawa, Sheik Said Island, Dur-gam Island, Gurgussum; other parts of the Dahlak Archipelago, including Nokra Island (Lipkin \& Silva, 2002). Red Sea: Sudan, Egypt, Yemen. Western Indian Ocean: SWIO, NWIO, Arabian Gulf.

Specimens studied: ER-RH-177, 178.

Gelidiella lubrica (Kütz.) Feldmann \& Hamel

Literature - Hatta \& Prud'homme van Reine, 1991.

Distribution - Eritrea: Nokra Island, Marine Station; Dahlak Archipelago (Lipkin \& Silva, 2002). Western Indian Ocean: SWIO.

Specimen studied: ER-RH-179.

Gelidiella myrioclada (Børgesen) Feldmann \& Hamel - Fig. 9

Literature - Jaasund, 1976; Hatta \& Prud'homme van Reine, 1991.

Distribution - Eritrea: Nokra Island, Dissei Island; other parts of the Dahlak Archipelago (Lipkin \& Silva, 2002). Western Indian Ocean: SWIO, NWIO, Arabian Gulf.

Specimens studied: ER-RH-181, 182.

Gelidiella spec. - Fig. 6-8

Distribution - Eritrea: Sheik Said Island, Gurgussum.

Note - This collection resembles Gelidiella myrioclada in its branching patterns. Its large size $(5-7 \mathrm{~cm})$ and cell arrangement in cross section show considerable variation.

Specimen studied: ER-RH-183.

GELIDIUM J.V. Lamour.

Gelidium spec. - Fig. 11

Distribution - Eritrea: Nokra Island.

Note - A small (c. $2.5 \mathrm{~cm}$ high) greenish plant. Branching is opposite. Branches are as long as the main axes and tapered at the tip, sometimes becoming thin as a hair.

Specimen studied: ER-RH-184.

PTEROCLADIELla Santel. \& Hommers.

The main criteria that were used to separate Pterocladia from Gelidium are: 1) unilocular cystocarps with ostioles only on one surface; 2) concentration of internal rhizines in the medulla; 3 ) surface view of outer cortical cells of erect axes is elongate, with the longer cell axis parallel to the axis of the thallus; and 4) an apical cell of erect branches located 

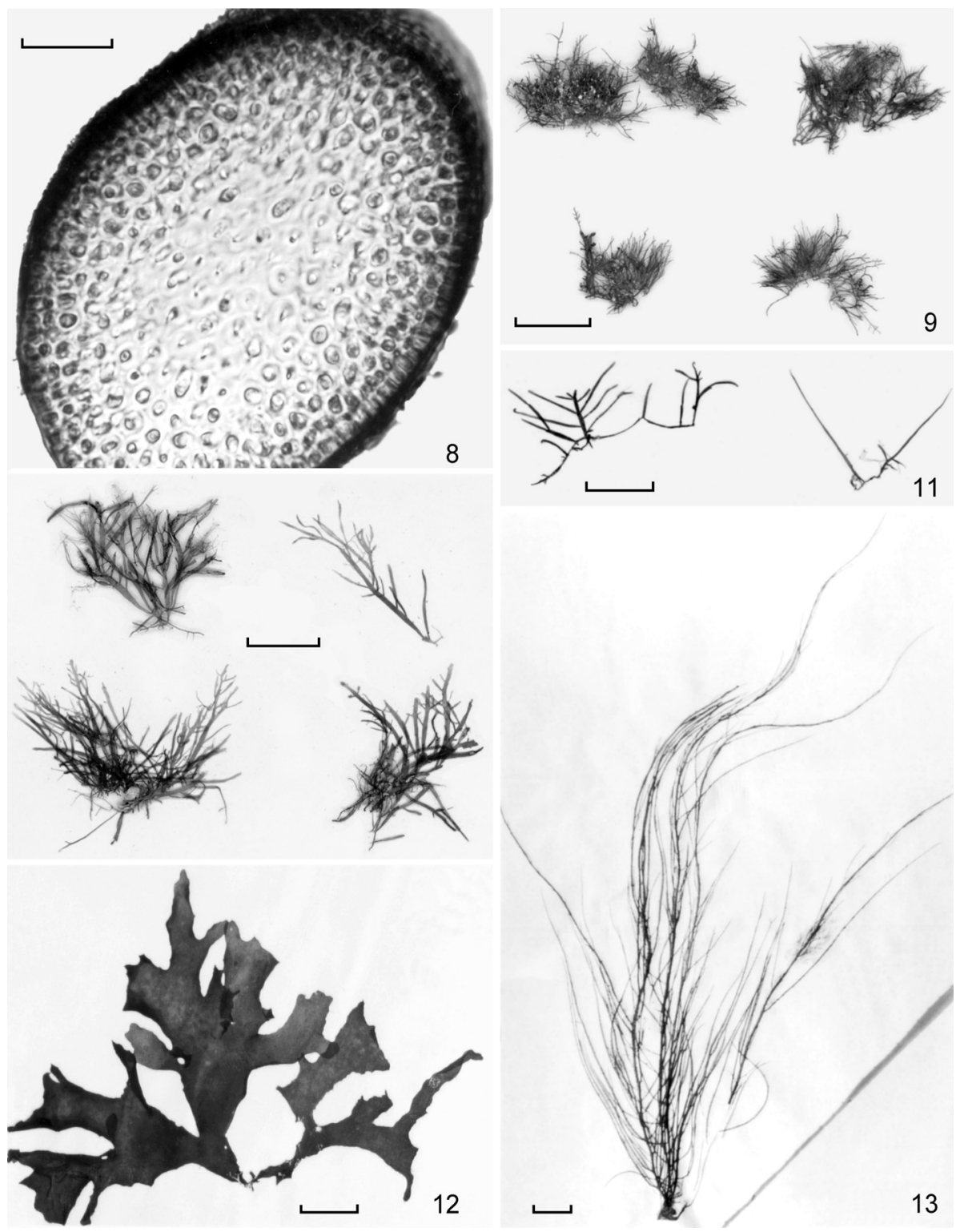

Fig. 8-13. - 8. Gelidiella spec.: cross section of the main axis. - 9. Gelidiella myrioclada: habit. - 10. Pterocladiella caerulescens: habit. -11 . Gelidium spec.: habit. -12 . Gracilaria vieillardii: habit. -13 . Gracilaria spec. 1 : habit. - Scale bars: $8=200 \mu \mathrm{m} ; 9=4 \mathrm{~mm} ; 10=9 \mathrm{~mm} ; 11,13=$ $10 \mathrm{~mm} ; 12=11 \mathrm{~mm}$.

in a notch. On the other hand, Gelidium has bilocular cystocarps and a concentration of rhizines in the subcortical region. Cortical cells in Gelidium are not elongated parallel to the axis and apical cells are not immersed in a notch (Norris, 1992; Stewart, 1992; Rodríguez \& Santelices, 1988). Santelices \& Hommersand (1997) detected Pterocladia 
specimens in which a small percentage of the cystocarps seem to have two unequally developed locules, which are directed to both surfaces of the thallus. They proposed to accommodate these algae in a genus they newly described as Pterocladiella. The distinctive characters for that genus are its intercalary carpogonia, which are directed towards both surfaces of the thallus, its nutritive filaments that are growing centripetally and form a virtually solid cylinder around the central axis and its gonimoblasts, which are usually attached to one side of the cystocarp floor with chains of carposporangia on the remaining three sides. These results are supported by molecular evidence (Santelices \& Hommersand, 1997). Santelices (1998) stated that Stewart (1968) has synonymised Pterocladia nana with Pterocladia capillacea. Shimada et al. (2000) studied Japanese Pterocladia species and, although their results are not very convincing, they transferred Pterocladia nana to the genus Pterocladiella.

1a. Thallus parts cylindrical to compressed, dark green to almost black, monoecious $\ldots \ldots \ldots \ldots \ldots \ldots \ldots \ldots \ldots \ldots \ldots \ldots \ldots \ldots \ldots \ldots \ldots \ldots \ldots$ caerulescens

b. Thallus parts cylindrical to flattened, reddish brown, without spermatangia on the carpogonium-producing branchlets . . . . . . . . . . . . . . Pillacea

**Pterocladiella caerulescens (Kütz.) Santel. \& Hommers. - Fig. 10

Literature - Hatta \& Prud'homme van Reine, 1991; Santelices \& Hommersand, 1997.

Distribution - Eritrea: Nokra Island, Marine Station. Western Indian Ocean: NWIO.

Specimens studied: ER-RH-288, 289, 291, 292.

**Pterocladiella capillacea (S.G. Gmel.) Santel. \& Hommers.

Pterocladia nana Okamura

Literature - Jaasund, 1976.

Distribution - Eritrea: Marine Station, Sheik Said Island. Western Indian Ocean: SWIO, NWIO.

Note - This species is different from the recently described Pterocladiella microscopica Lipkin \& Papenf. (Lipkin \& Silva, 2002).

Specimen studied: ER-RH-293.

\section{GRACILARIALES}

GRACILARIA Grev.

1a. Thallus flattened except at the stipe. . . . . . . . . . . . . . . . 2

b. Thallus cylindrical or compressed. . . . . . . . . . . . . . . 4

2a. Marginal projections normally present, thallus margins remarkably dentate ..... $\ldots \ldots \ldots \ldots \ldots \ldots \ldots \ldots \ldots \ldots \ldots \ldots \ldots \ldots \ldots \ldots \ldots \ldots$. vieillardii

b. Branching primarily dichotomous, with many lateral branchlets, marginal projections absent or rare . . . . . . . . . . . . . . . . . 3 
3a. Branches of less than three orders, margins with few dentations or small spine-like projections

G. corallicola

b. Branches of more than three orders, branching primarily dichotomous with many lateral branchlets (masking the dichotomies) . . . . . . . . . G. corticata

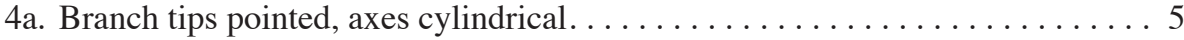

b. Branch tips rounded, axes usually compressed . . . . . . . . . . . . 6

5a. Axes filiform, about $1 \mathrm{~mm}$ thick, branches tapering at both ends, small spine-like ramuli present $\ldots \ldots \ldots \ldots \ldots \ldots \ldots$ Gracilaria spec. 1

b. Thallus robust, main axes usually thicker than $1.5 \mathrm{~mm}$, branches often of two

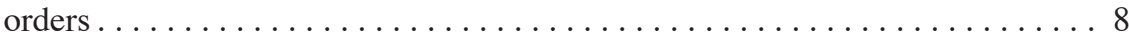

6a. Arcuate plants, about $3 \mathrm{~mm}$ thick, irregularly branched, sometimes unilateral ...

G. arcuata

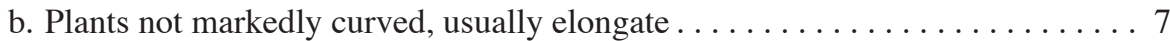

7a. Plants 7-10 cm long, fleshy, irregularly branched, branching more pronounced in the upper parts, dried specimens become highly compressed and adhere firmly to the paper. . . . . . . . . . . . . . . . . . Gracilaria spec. 2

b. Plants up to $20 \mathrm{~cm}$ high, branching nearly dichotomous, on the whole irregular. Substance rather stiff and dried specimens do not adhere to the paper. . G. edulis

8a. Decumbent, prostrate thalli, axes normally more than $2 \mathrm{~mm}$ wide and constricted

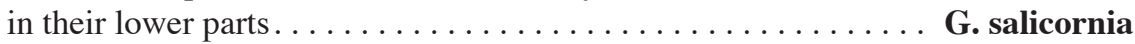

b. Erect thalli, dichotomous above, not branched below, axes 3-4 mm thick, thallus fleshy, not constricted

G. debilis

\section{Gracilaria arcuata Zanardini}

Literature - Jaasund, 1976.

Distribution - Eritrea: Assab Bay, Gurgussum, Dur-gam Island; other parts of the Dahlak Archipelago (Lipkin \& Silva, 2002). Red Sea: Egypt. Western Indian Ocean: SWIO, NWIO.

Specimens studied: ER-RH-186-190

**Gracilaria corallicola Zanardini - Fig. 14

Literature - Hoyle, 1994.

Distribution - Eritrea: Dur-gam Island.

Specimen studied: ER-RH-208

**Gracilaria corticata (J. Agardh) J. Agardh

Literature - Jaasund, 1976.

Distribution - Eritrea: Gurgussum, Sheik Said Island. Western Indian Ocean: SWIO, NWIO, Arabian Gulf.

Specimens studied: ER-RH-195, 196. 

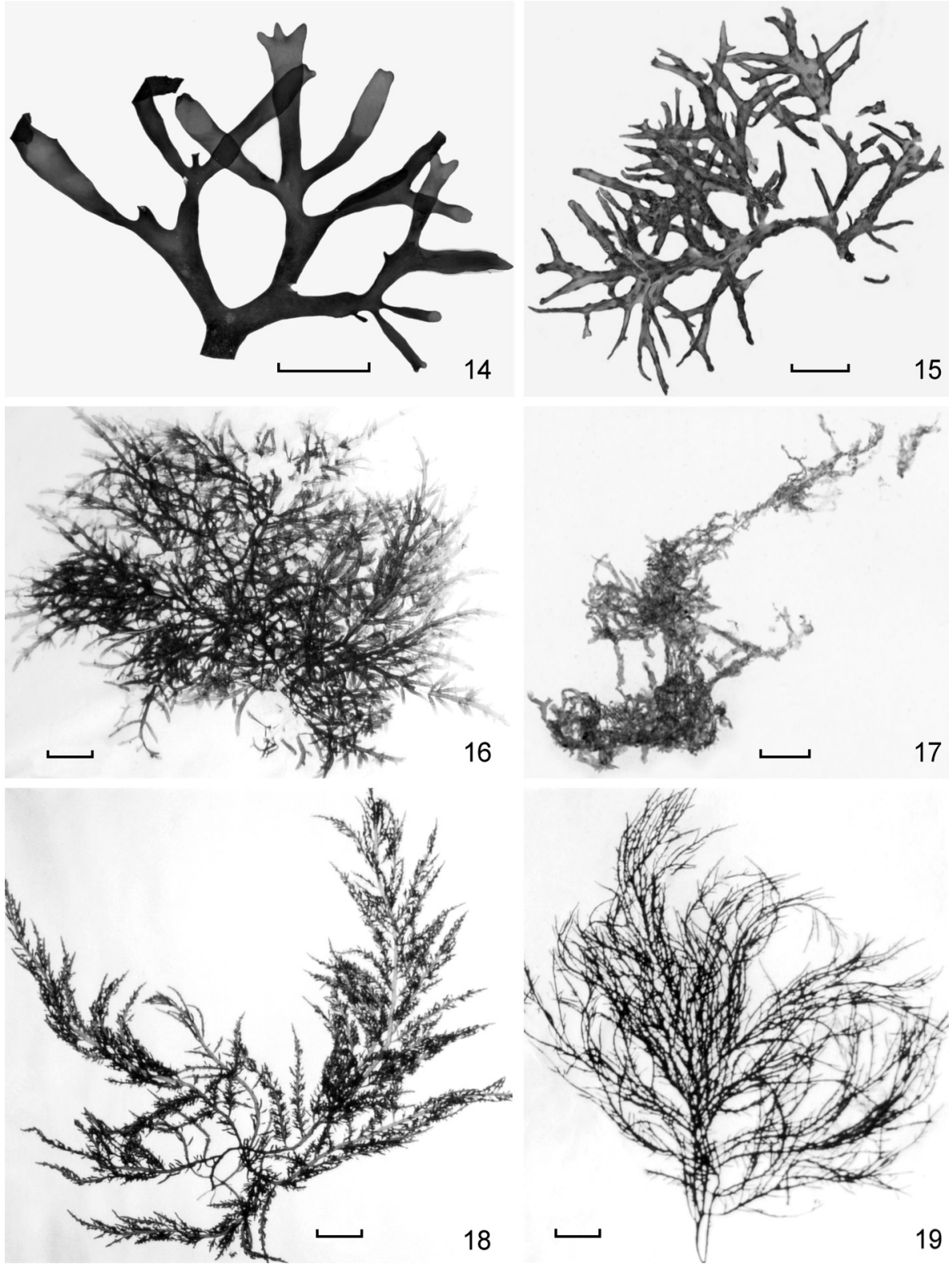

Fig. 14-19. - 14. Gracilaria corallicola: habit. - 15. Gracilaria spec. 2: habit. - 16. Champia spec.: habit. - 17. Martensia fragilis: habit. - 18. Chondria sedifolia: habit. - 19. Chondria dasyphylla: habit. - Scale bars: all $=10 \mathrm{~mm}$. 
Gracilaria debilis (Forssk.) Børgesen

Gracilaria fergusonii J. Agardh

Literature - Jaasund, 1976; Silva et al., 1996.

Distribution - Eritrea: Assab Bay, Gurgussum; Dahlak Archipelago (Lipkin, 1987; Lipkin \& Silva, 2002). Red Sea: Yemen. Western Indian Ocean: SWIO, NWIO.

Specimen studied: ER-RH-205.

**Gracilaria edulis (S.G. Gmel.) P.C. Silva

Literature - Jaasund, 1976.

Distribution - Eritrea: Gurgussum. Western Indian Ocean: SWIO, NWIO.

Specimen studied: ER-RH-209.

Gracilaria salicornia (J. Agardh) E.Y. Dawson

Gracilaria cacalia (J. Agardh) E. Y. Dawson

Literature - Jaasund, 1976; Wynne, 1995; Silva et al., 1996.

Distribution - Eritrea: Assab Bay, Massawa, Gurgussum; Mandola, Sheik Said Island, Dissei Island, Dur-gam Island, Dur-gella Island, Nokra Island; other parts of the Dahlak Archipelago (Lipkin \& Silva, 2002). Red Sea: Egypt, Saudi-Arabia, Yemen. Western Indian Ocean: SWIO, NWIO, Arabian Gulf.

Note - For a discussion on synonymy of G. salicornia with G. canaliculata Sond. and G. crassa (Harv.) J. Agardh see Silva et al. (1996). We have followed Wynne (1995).

Specimens studied: ER-RH-203, 204.

**Gracilaria vieillardii P.C. Silva - Fig. 12

Gracilaria denticulata (Kütz.) Weber Bosse

Literature - Norris, 1985.

Distribution - Eritrea: Dur-gam Island. Western Indian Ocean: SWIO, NWIO.

Specimens studied: ER-RH-209-213, 218.

Gracilaria spec. 1 - Fig. 13

Distribution - Eritrea: Hirghigo.

Note - The collection shares characteristics mentioned for G. tenuistipitata C.F. Chang \& B.M. Xia var. tenuistipitata and G. manilaensis H. Yamam. \& Trono.

Specimen studied: ER-RH-220.

Gracilaria spec. 2 - Fig. 15

Distribution - Eritrea: Gurgussum. 
Note - Thalli are fleshy and irregularly branched, mainly in the upper parts. Dried specimens become highly compressed and adhere to the paper firmly. It is distributed in the higher part of the mid-intertidal subzone of Gurgussum beach.

Specimen studied: ER-RH-221.

\section{CRYPTONEMIALES}

HALYMENia C. Agardh

\section{Halymenia dilatata Zanardini}

Literature - Verheij \& Prud'homme van Reine, 1993.

Distribution - Eritrea: Massawa, Dur-gam Island. Western Indian Ocean: SWIO, NWIO.

Note - Plants form gelatinous and thin entire blades, which are irregularly shaped and densely covered with dark spots. Generally they are longer than broad and attached to the substratum by a small stipe. They are often more than $15 \mathrm{~cm}$ long and more than $10 \mathrm{~cm}$ wide.

Specimen studied: ER-RH-222.

\section{CORALLINALES}

JANIA J.V. Lamour.

Jania adhaerens J. V. Lamour.

Literature - Jaasund, 1976.

Distribution - Eritrea: Gulf of Zula, Dissei Island, Nokra Island, Dur-gam Island; other parts of the Dahlak Archipelago (Lipkin \& Silva, 2002). Red Sea: Egypt. Western Indian Ocean: SWIO, NWIO.

Note - Plants have prostrate and erect parts, 1-2 cm long. The thallus is repeatedly dichotomously branched, with conical apices, and with segments which taper towards the apex. Plants are growing on rocks in the higher intertidal or epiphytically on Sargassum and Hormophysa.

Specimen studied: ER-RH-301.

\section{GIGARTINALES}

HYPNEA J.V. Lamour.

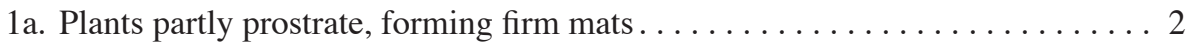

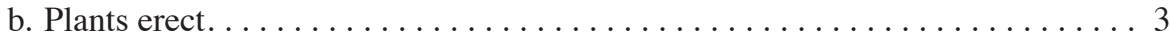

2a. Thallus purple, with blue iridescence, axes compressed and more than $1.5 \mathrm{~mm}$ broad, branches frequently anastomosing, nemathecia not embracing branchlets . 
b. Thallus bleached, straw coloured, thallus nearly terete or little compressed, $0.5-1.5$ $\mathrm{mm}$ thick, not anastomosing, tetrasporangia in saddle shaped nemathecia.

H. nidulans

3a. Densely branched plants with distinct main axes, apex of branchlets cervicorn. . .

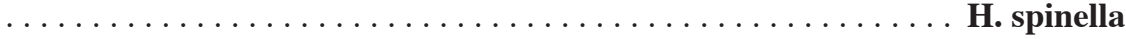

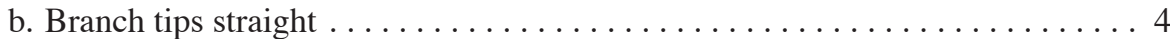

4a. Branchlets clothing axes and branches simple ......... H. valentiae

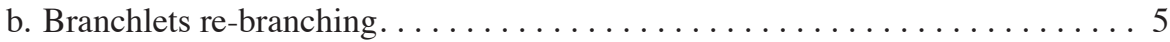

5a. Branchlets highly crowded, re-branching and provided with numerous short spines, nemathecia embracing branchlets . . . . . . . . hamulosa

b. Branchlets sparse, slender and much branched, without spines, branching divaricate with partly naked branches, main axes about $1 \mathrm{~mm}$ thick with abrupt transition to branchlets, nemathecia unknown. . . . . . . . . . . . nidifica

**Hypnea hamulosa (Esper) J. V. Lamour.

Hypnea cornuta (Kütz.) J. Agardh

Literature - Jaasund, 1976.

Distribution - Eritrea: Dur-gam Island, Nokra Island, Sheik Said Island. Western Indian Ocean: NWIO.

Specimen studied: ER-RH-232.

\section{Hypnea nidifica J. Agardh}

Literature - Jaasund, 1976.

Distribution - Eritrea: Sheik Said Island, Mandola Island, Gurgussum. Western Indian Ocean: SWIO, NWIO.

Specimens studied: ER-RH-233-235.

\section{**Hypnea nidulans Setch.}

Literature - Jaasund, 1976.

Distribution - Eritrea: Gurgussum, Nokra Island, Dissei Island, Dur-gam Island, Sheik Said Island. Western Indian Ocean: SWIO, NWIO.

Specimen studied: ER-RH-240.

\section{**Hypnea pannosa J. Agardh}

Literature - Jaasund, 1976; Haroun \& Prud'homme van Reine, 1993.

Distribution - Eritrea: Dur-gam Island, Gurgussum. Western Indian Ocean: SWIO, NWIO, Arabian Gulf

Specimens studied: ER-RH-245, 246 
Hypnea spinella (C. Agardh) Kütz.

Hypnea cervicornis J. Agardh

Literature - Haroun \& Prud'homme van Reine, 1993.

Distribution - Eritrea: Gurgussum, Massawa, Nokra Island. Western Indian Ocean: SWIO, NWIO.

Specimens studied: ER-RH-243, 244.

Hypnea valentiae (Turner) Mont.

Literature - Børgesen, 1940-1957.

Distribution - Eritrea: Bay of Assab, Gulf of Zula, Gurgussum, Hirghigo, Shuma, Sheik Said Island, Nokra Island, Massawa; other parts of the Dahlak Archipelago (Lipkin \& Silva, 2002). Red Sea: Sudan, Egypt, Jordan, Saudi-Arabia, Yemen. Western Indian Ocean: SWIO, NWIO, Arabian Gulf.

Note - Differently from Lipkin \& Silva (2002) we consider Hypnea cornuta (Kütz.) J. Agardh and H. hamulosa to be synonyms, but we consider $H$. valentiae as a separate species.

Specimens studied: ER-RH-247-257.

\section{SARCONEMA Zanardini}

Sarconema filiforme (Sond.) Kylin

Sarconema furcellatum Zanardini

Literature - Jaasund, 1976; Papenfuss \& Edelstein, 1974; Silva et al., 1996.

Distribution - Eritrea: Assab Bay, Gulf of Zula, Gurgussum, Massawa, Dur-gam Island, Sheik Said Island, Nokra Island; other parts of the Dahlak Archipelago (Lipkin \& Silva, 2002). Red Sea: Sudan, Egypt, Yemen. Western Indian Ocean: SWIO, NWIO, Arabian Gulf.

Specimens studied: ER-RH-294-296, 300.

\section{RHODYMENIALES}

BOTRYOCLADIA (J. Agardh) Kylin

\section{Botryocladia skottsbergii Børgesen}

Literature - Jaasund, 1976.

Distribution - Eritrea: Dissei Island; other parts of the Dahlak Archipelago (Lipkin \& Silva, 2002). Western Indian Ocean: SWIO, NWIO.

Note - The thallus is composed of terete and solid branches terminating into globular or pyriform bladders filled with mucilage. The plants are 1-2 cm high.

Specimen studied: ER-RH-155. 


\section{ChAmpia Desv.}

1a. Thallus wall consisting of a single cell layer. . . . . . . . . . . . 2

b. Thallus wall of two cell layers, thallus thin with rectangularly inserted branchlets $\ldots \ldots \ldots \ldots \ldots \ldots \ldots \ldots \ldots \ldots \ldots \ldots \ldots \ldots \ldots \ldots \ldots \ldots$. irregularis

2a. Small and irregularly branching plant ............. parvula

b. Erect plants about $10 \mathrm{~cm}$ high, branching frequently opposite, sometimes more than one branch emerging from a segment .......... Champia spec.

Champia irregularis (Zanardini) Picc.

Literature - Jaasund, 1976.

Distribution - Eritrea: Assab Bay, Dur-gam Island; other parts of the Dahlak Archipelago (Lipkin \& Silva, 2002). Red Sea: Egypt, Yemen. Western Indian Ocean: SWIO, NWIO.

Specimen studied: ER-RH-161.

Champia parvula (C. Agardh) Harv.

Literature - Jaasund, 1976.

Distribution - Eritrea: Nokra Island; other parts of the Dahlak Archipelago (Lipkin \& Silva, 2002). Red Sea: Egypt, Saudi-Arabia. Western Indian Ocean: SWIO, NWIO, Arabian Gulf.

Specimens studied: ER-RH-163, 164.

\section{Champia spec. - Fig. 16}

Distribution - Eritrea: Gurgussum.

Note - This collection consists of an erect plant of about $8 \mathrm{~cm}$ high. The thallus is about $2 \mathrm{~mm}$ thick, with isodiametric segments. In cross section, the thallus wall is monostromatic. Branching is mostly opposite; sometimes 3 or 4 branchlets arise from the same segment.

Specimen studied: ER-RH-165.

\section{COELOTHRIX Børgesen}

\section{Coelothrix irregularis (Harv.) Børgesen}

Literature - Jaasund, 1976.

Distribution - Eritrea: Dur-gam Island; other parts of the Dahlak Archipelago (Lipkin, 1987; Lipkin \& Silva, 2002). Western Indian Ocean: SWIO, NWIO.

Specimens studied: ER-RH-173, 174. 


\section{GELIDIOPSIS Zanardini}

Gelidiopsis variabilis (J. Agardh) F. Schmitz

Ceratodictyon variabilis (J. Agardh) R.E. Norris

Gelidiopsis repens (Kütz.) Weber Bosse

Gelidiopsis acrocarpa (Harv. ex Kütz.) De Toni

Literature - Verheij \& Prud'homme van Reine, 1993.

Distribution - Eritrea: Gurgussum, Sheik Said Island, Nokra Island; other parts of the Dahlak Archipelago (Lipkin \& Silva, 2002). Western Indian Ocean: SWIO, NWIO.

Note - We consider Gelidiopsis acrocarpa, G. repens and G. variabilis as belonging to a single species on the basis of (unpublished) research by A.M. Hatta.

Specimen studied: ER-RH-160.

\section{CERAMIALES}

ACANTHOPHORA J.V. Lamour.

1a. Main axes spinous, branch tips blunt, spines distributed from the base to the end

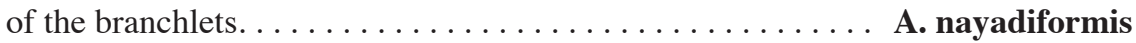

b. Main axes not spinous, spines mainly on the upper parts, branch tips pointed. . .

A. spicifera

Acanthophora nayadiformis (Delile) Papenf. - Fig. 20

Literature - De Jong et al., 1999.

Distribution - Eritrea: Assab Bay, Massawa, Sheik Said Island; Dahlak Archipelago (Lipkin, 1987; Lipkin \& Silva, 2002). Red Sea: Egypt, Jordan, Saudi-Arabia, Yemen. Western Indian Ocean: NWIO, Arabian Gulf.

Specimen studied: ER-RH-151.

**Acanthophora spicifera (Vahl) Børgesen - Fig. 21

Literature - Jaasund, 1976; De Jong et al., 1999.

Distribution - Eritrea: Gurgussum, Nokra Island, Sheik Said Island. Western Indian Ocean: SWIO, NWIO, Arabian Gulf.

Specimens studied: ER-RH-152, 153

\section{Caloglossa (Harv.) G. Martens}

\section{Caloglossa leprieurii (Mont.) G. Martens}

Literature - Jaasund, 1976.

Distribution - Eritrea: Hirghigo; Melita Bay: Gulf of Zula (Lipkin, 1987; Lipkin \& Silva, 2002). Western Indian Ocean: SWIO, NWIO.

Specimen studied: ER-RH-156. 


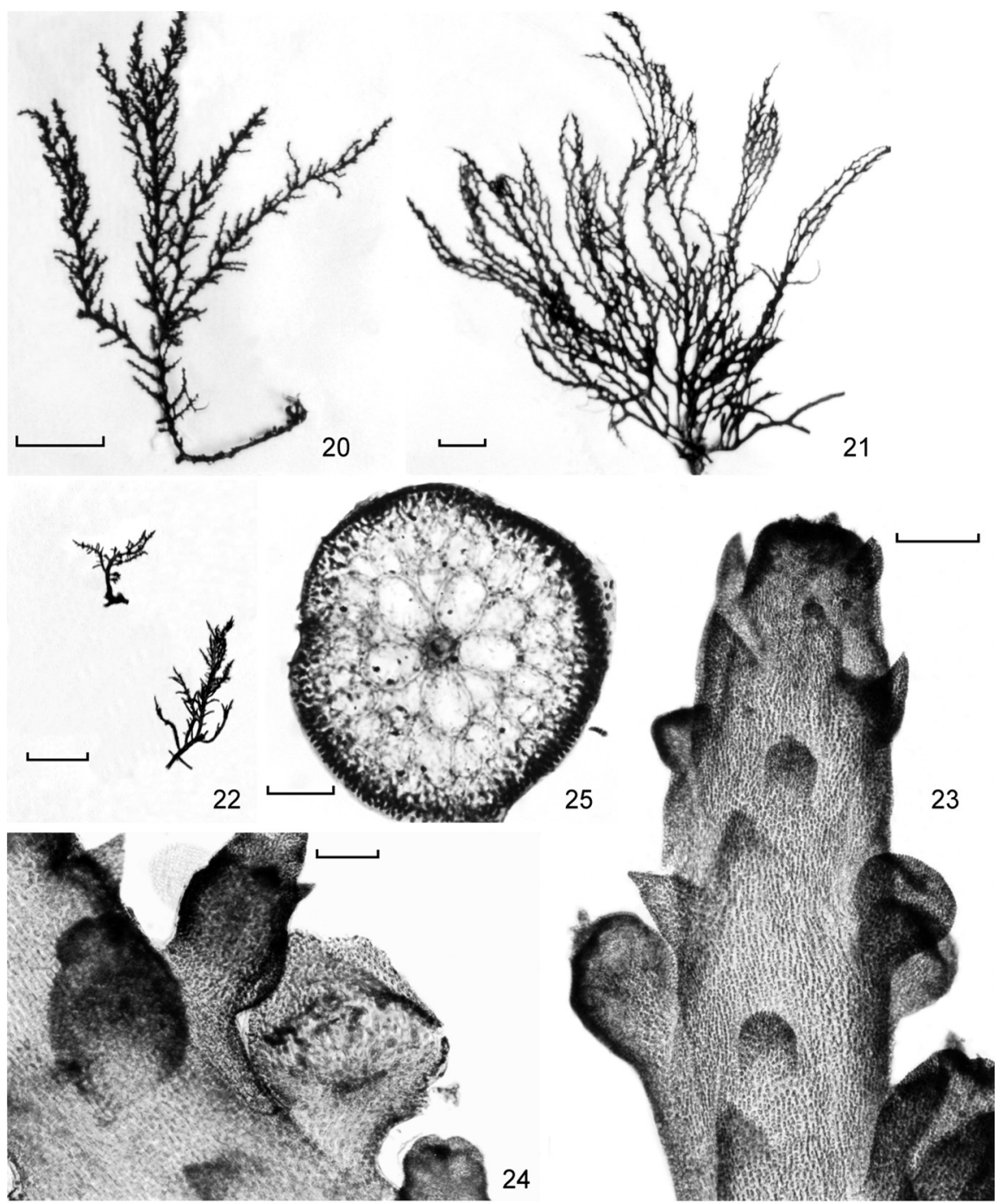

Fig. 20-25. - 20. Acanthophora nayadiformis: habit. - 21. Acanthophora spicifera: habit. $-22-25$. Chondria spec. 22. Habit; 23. branch tip with spinous ramuli; 24. cystocarp on a branch; 25. cross section of main axis. - Scale bars: $20,21=10 \mathrm{~mm} ; 22=5 \mathrm{~mm} ; 23=350 \mu \mathrm{m} ; 24,25=200 \mu \mathrm{m}$.

\section{Centroceras (C. Agardh) Mont.}

Centroceras clavulatum (C. Agardh) Mont.

Literature - Jaasund, 1976.

Distribution - Eritrea: Marine Station; Dahlak Archipelago (Lipkin \& Silva, 2002). Red Sea: Egypt, Jordan. Western Indian Ocean: SWIO, NWIO, Arabian Gulf.

Specimen studied: ER-RH-157. 


\section{CERAMIUM Roth}

\section{Ceramium flaccidum (Kütz.) Ardiss.}

Ceramium gracillimum (Kütz.) B.M. Griffiths \& Harv.

Ceramium masonii E. Y. Dawson

Literature - Jaasund, 1976; Silva et al., 1996.

Distribution - Eritrea: Assab Bay, Massawa, Marine Station; Dahlak Archipelago (Lipkin \& Silva, 2002). Red Sea: Egypt, Israel, Saudi-Arabia. Western Indian Ocean: SWIO, NWIO, Arabian Gulf.

Specimen studied: ER-RH-159.

\section{CHONDRIA C. Agardh}

1a. Axes and branches bearing spines.............. Chondria spec.

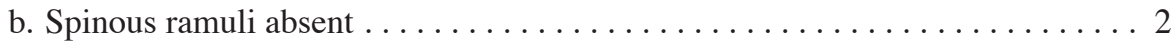

2a. Plants small and with pericentral cell wall thickenings; epiphytic on seagrasses. .

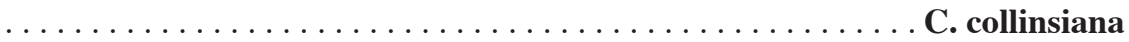

b. Plants relatively large; pericentral cell wall thickenings absent . . . . . . . 3

3a. Bushy plants, branches spreading; conspicuous tuft of trichoblasts present at each apex, dried plants turn brown to pale straw in colour . . . . . . . . C. dasyphylla

b. Plants pyramidal (triangular) in outline and bushy; axes straight, colour reddish

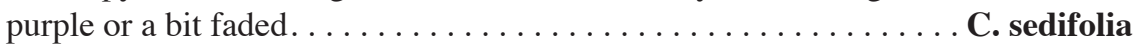

\section{Chondria collinsiana M. Howe}

Literature - Jaasund, 1976.

Distribution - Eritrea: Nokra Island; other parts of the Dahlak Archipelago (Lipkin \& Silva, 2002). Red Sea: Egypt. Western Indian Ocean: NWIO, Arabian Gulf.

Specimen studied: ER-RH-166.

Chondria dasyphylla (Woodw.) C. Agardh - Fig. 19

Literature - Jaasund, 1976.

Distribution - Eritrea: Hirghigo; Dahlak Archipelago (Lipkin, 1987; Lipkin \& Silva, 2002). Red Sea: Saudi-Arabia. Western Indian Ocean: SWIO, NWIO, Arabian Gulf.

Specimen studied: ER-RH-167.

*Chondria sedifolia Harv. - Fig. 18

Literature - Jaasund, 1976.

Distribution - Eritrea: Sheik Said Island, Gurgussum. Red Sea: Egypt. Western Indian Ocean: NWIO.

Specimen studied: ER-RH-170. 
Chondria spec. - Fig. 22-25

Distribution - Eritrea: Dur-gam Island.

Note - This fragment of a Chondria species is unique in the presence of spines on the branches and branchlets. It was only $10 \mathrm{~cm}$ high and collected from a depth of $4 \mathrm{~m}$. The pinkish red colour is still present in the dried specimen. Branching from the axes (c. $2 \mathrm{~mm}$ diam.) is radial and non-spreading, with up to about four orders; sparse in the lower parts and tending to be prolific towards the tips. Branch sizes are irregular and the spindle-shaped branchlets $(0.2-1 \mathrm{~mm}$ diam.) are produced singly and radially and are mostly basally constricted. The apices of the axes and branchlets are rounded to flattened and beset with spines, while the branchlets may have an apical central depression. The surface of branches and branchlets is covered by acute spines (spurs). Cystocarps are subtending to the spines or are formed proximal to a spine. Whereas the morphology of the branchlets and the arrangement of the pericentral cells agree with Chondria, the presence of spines suggests Acanthophora. Weber-van Bosse (1910) established the genus Acanthochondria to accommodate a species (Acanthochondria falkenbergii Weber Bosse, later identified as Acanthophora dendroides Harv.) that she considered intermediate in morphology between Chondria and Acanthophora. The present specimen, however, differs considerably from that species in the form and arrangement of the spines.

Specimen studied: ER-RH-172.

\section{ChONDROPHYCUS (Tokida \& Y. Saito) Garbary \& J.T. Harper}

1a. Fronds with terete axes, densely covered with wart-like ultimate branchlets, cortical cells palisade-like. ................... papillosus

b. Fronds with (partly) compressed main axes, ultimate branchlets terete and only slightly covered with wart-like outgrowths, cortical cells not palisade-like... . 2

2a. Fronds fleshy, with slightly but constantly compressed axes and branches, branching alternate or pinnate $\ldots \ldots \ldots \ldots \ldots \ldots \ldots \ldots \ldots \ldots \ldots \ldots \ldots \ldots \ldots \ldots$ dotyi

b. Fronds cartilaginous, with irregularly branched axes, terete below and angular to compressed upward $\ldots \ldots \ldots \ldots \ldots \ldots \ldots \ldots \ldots \ldots \ldots \ldots \ldots \ldots$. cartilagineus

**Chondrophycus cartilagineus (Yamada) Garbary \& J.T. Harper

Laurencia cartilaginea Yamada

Literature - Yamada, 1931; Garbary \& Harper, 1998.

Distribution - Eritrea: Dissei Island, Dur-gam Island.

Specimens studied: ER-RH-259, 260.

**Chondrophycus dotyi (Y. Saito) K. W. Nam

Laurencia dotyi Y. Saito

Literature - Yamada, 1931; Verheij \& Prud'homme van Reine, 1993; Nam, 1999.

Distribution - Eritrea: Dissei Island, Dur-gam Island.

Specimens studied: ER-RH-262, 263. 
Chondrophycus papillosus (C. Agardh) Garbary \& J.T. Harper

Laurencia papillosa (C. Agardh) Grev.

Literature - Yamada, 1931; Jaasund, 1976; Garbary \& Harper, 1998.

Distribution - Eritrea: Assab Bay, Gulf of Zula, Massawa, Gurgussum, Shuma, Dur-gam Island, Dur-gella Island, Sheik Said Island, Nokra Island, Dissei Island; other parts of the Dahlak Archipelago (Lipkin, 1987; Lipkin \& Silva, 2002). Red Sea: Sudan, Egypt, Saudi-Arabia, Yemen. Western Indian Ocean: SWIO, NWIO, Arabian Gulf.

Specimens studied: ER-RH-279-282.

\section{CORALlOPHILA Weber Bosse}

**Corallophila huysmansii (Weber Bosse) R.E. Norris

Ceramiella huysmansii (Weber Bosse) Børgesen

Ceramium huysmansii Weber Bosse

Literature - Hommersand, 1963.

Distribution - Eritrea: Sheik Sahid Island, Nokra Island. Western Indian Ocean: SWIO, NWIO.

Specimens studied: ER-RH-157, 158.

\section{DASYA C. Agardh}

Dasya baillouviana (S.G. Gmel.) Mont.

Literature - Coppejans, 1983.

Distribution - Eritrea: Nokra Island; other parts of the Dahlak Archipelago (Lipkin, 1987; Lipkin \& Silva, 2002). Western Indian Ocean: SWIO, NWIO, Arabian Gulf.

Specimen studied: ER-RH-175.

\section{HERPOSIPHONIA Nägeli}

**Herposiphonia secunda (C. Agardh) Ambronn

Literature - Jaasund, 1976.

Distribution - Eritrea: Marine Station. Western Indian Ocean: SWIO, NWIO.

Specimen studied: ER-RH-223.

LAURENCIA J.V. Lamour.

1a. Thallus compressed throughout, with very short tuberculate ultimate branchlets

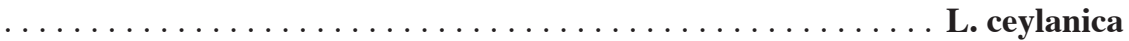

b. Fronds not compressed, ultimate branchlets clavate . . . . . . . . . 2

2a. Small prostrate plants with abundant lenticular cell-wall thickenings in the medul-

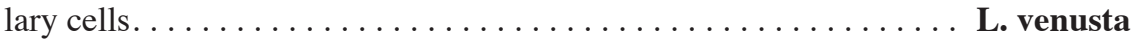

b. Erect plants with well-defined repeatedly branched paniculate axes, no lenticular cell-wall thickenings in the medullary cells ............. obtusa 


\section{**Laurencia ceylanica J. Agardh}

Literature - Yamada, 1931.

Distribution - Eritrea: Dur-gam Island. Western Indian Ocean: NWIO.

Specimen studied: ER-RH-261.

Laurencia obtusa (Huds.) J.V. Lamour.

Literature - Yamada, 1931; Jaasund, 1976.

Distribution - Eritrea: Gurgussum, Sheik Said Island, Dissei Island, Nokra Island, Dur-gam Island, Dur-gella Island; other parts of the Dahlak Archipelago (Lipkin \& Silva, 2002). Red Sea: Sudan, Egypt, Jordan, Saudi-Arabia, Yemen. Western Indian Ocean: SWIO, NWIO, Arabian Gulf.

Specimens studied: ER-RH-267, 268, 273, 274.

\section{Laurencia venusta Yamada}

Literature - Yamada, 1931; Jaasund, 1976.

Distribution - Eritrea: Sheik Said Island; Dahlak Archipelago (Lipkin \& Silva, 2002). Western Indian Ocean: NWIO.

Specimen studied: ER-RH-283.

\section{LEVEILLEA Decne.}

Leveillea jungermannioides (Hering \& G. Martens) Harv.

Literature - Scagel \& Chihara, 1968; Jaasund, 1976.

Distribution - Eritrea: Bay of Assab, Dur-gam Island, Massawa, Gurgussum; other parts of the Dahlak Archipelago (Lipkin \& Silva, 2002). Red Sea: Sudan, Egypt. Western Indian Ocean: SWIO, NWIO, Arabian Gulf.

Specimen studied: ER-RH-284.

\section{MARTENSIA Hering}

1a. Plants $2-8 \mathrm{~cm}$ long, fan shaped. ........................ elegans

b. Plants forming delicate mucilaginous membranes, usually more than $10 \mathrm{~cm}$ long M. fragilis

\section{Martensia elegans Hering}

Literature - Jaasund, 1976.

Distribution - Eritrea: Mandola Island, Dissei Island, Dur-gam Island, Dur-gella Island; other parts of the Dahlak Archipelago (Lipkin, 1987; Lipkin \& Silva, 2002). Western Indian Ocean: SWIO, NWIO.

Specimen studied: ER-RH-285. 
**Martensia fragilis Harv. - Fig. 17

Literature - Silva et al., 1996.

Distribution - Eritrea: Nokra Island.

Specimen studied: ER-RH-286.

POLYSIPHONIA Grev.

**Polysiphonia coacta C.K. Tseng

Literature - Jaasund, 1976.

Distribution - Eritrea: Nokra Island. Western Indian Ocean: NWIO, Arabian Gulf. Specimen studied: ER-RH-287.

\section{INCERTAE SEDIS}

WURDEMANNIA Harv.

Wurdemannia miniata (Spreng.) Feldmann \& Hamel

Literature - Jaasund, 1976.

Distribution - Eritrea: Sheik Said Island; Dahlak Archipelago (Lipkin \& Silva, 2002). Western Indian Ocean: SWIO, NWIO, Arabian Gulf.

Note - Small (about $2 \mathrm{~cm}$ ) and wiry, mat forming plants. Branching is irregular, intricate and in all directions. Branches are terete to slightly compressed and with acute tips. Apical cells are numerous. Wurdemania is a genus of uncertain taxonomic position (Silva et al., 1996).

Specimen studied: ER-RH-294A.

PHAEOPHYTA

KEY TO THE GENERA OF PHAEOPHYTA FROM ERITREA

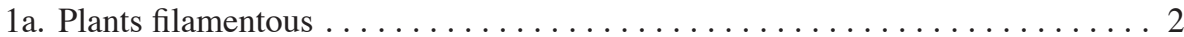

b. Plants frondose. . . . . . . . . . . . . . . . . . . . . . . . 3

2a. Filaments parenchymatic, growth from a conspicuous apical cell, lateral branches arising from the upper part of a segment; vegetative reproduction by distinctive propagules $\ldots \ldots \ldots \ldots \ldots \ldots \ldots \ldots \ldots \ldots \ldots \ldots \ldots \ldots \ldots$ Sphacelaria

b. Filaments uniseriate throughout, growth intercalary meristematic; sporangia inter-

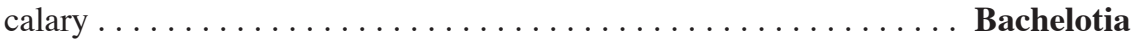

3a. Plants forming prostrate, leathery and crustose structures . . . . . Lobophora

b. Parenchymatous thallus, not crustose $\ldots \ldots \ldots \ldots \ldots \ldots \ldots \ldots$

4a. Thallus differentiated into distinct stipes and lateral blades; air bladders usually

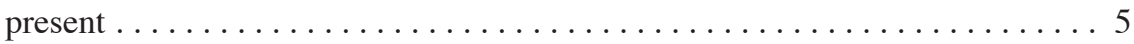

b. Thallus not clearly differentiated; air bladders absent. . . . . . . . . . 8 
5a. Vesicles borne in the axes $\ldots \ldots \ldots \ldots \ldots \ldots \ldots \ldots \ldots$ Hormophysa

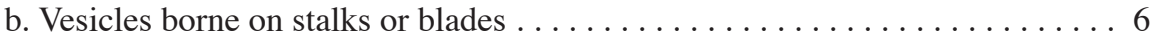

6 a. Vesicles in the centre of peltate blades. . . . . . . . . . . . Turbinaria

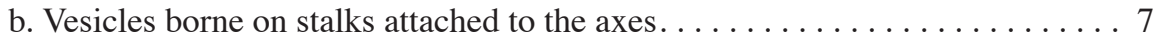

7a. Ultimate branchlets filiform or spine-like; air bladders and receptacles formed on the ordinary branches. .................... Cystoseira

b. Ultimate branchlets leaf-like; air bladders and receptacles lateral and axillary . .

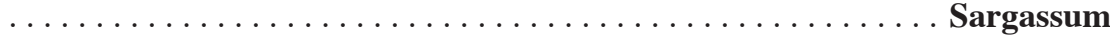

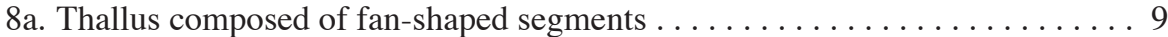

b. Thallus composed of strap-shaped segments . . . . . . . . . . . 10

9a. Apical or distal margins of fronds incurved or revolute, thallus usually calcified and with distinct concentric zones of hairs $\ldots \ldots \ldots \ldots \ldots \ldots$ Padina

b. Apical margins of fronds always flat, thallus not calcified, no zones of hairs

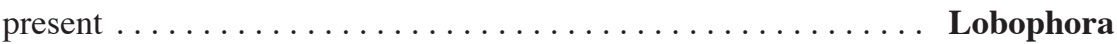

10a. Thallus regularly or irregularly branched, margins flat . . . . . . . Dictyota

b. Thallus regularly branched, apical margin inrolled ....... Stoechospermum

\section{ECTOCARPALES}

BACHELOTIA (Bornet) Kuck. ex Hamel

\section{**Bachelotia antillarum (Grunow) Gerloff}

Literature - Womersley, 1987.

Distribution - Eritrea: Nokra Island. Western Indian Ocean: SWIO, NWIO.

Note - Plants form tufts or mats of sparsely branched erect filaments arising from an entangled base. Hairs are absent. Unilocular sporangia are intercalary.

Specimen studied: ER-PH-050.

\section{SPHACELARIALES}

SPHACELARIA Lyngb.

1a. Propagules stout obconical to obtriangular, longer than broad, without or with very

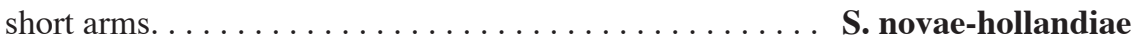

b. Propagules broadly obtriangular, as long as broad, arms explicit . . S. tribuloides

\section{*Sphacelaria novae-hollandiae Sond.}

Literature - Jaasund, 1976; Womersley, 1987.

Distribution - Eritrea: Dur-gam Island. Red Sea: Egypt. Western Indian Ocean: SWIO, NWIO, Arabian Gulf.

Note - The present collection resembles Sphacelaria novae-caledoniae Sauv. (Womersley, 1987), but presence of that Pacific and southern Australian species in the Red Sea is doubtful. Sphacelaria novae-hollandiae is a widely distributed taxon in the 
tropics. The identification was made before the publication by Keum et al. (2003), who discuss similarities between the two species.

Specimen studied: ER-PH-089.

\section{Sphacelaria tribuloides Menegh.}

Literature - Jaasund, 1976.

Distribution - Eritrea: Dur-gam Island, Assab Bay, Massawa; other parts of the Dahlak Archipelago (Lipkin \& Silva, 2002). Red Sea: Egypt, Israel. Western Indian Ocean: SWIO, NWIO, Arabian Gulf.

Specimen studied: ER-PH-090.

\section{DICTYOTALES}

DICTYOTA J. V. Lamour.

1a. Strap margins dentate $\ldots \ldots \ldots \ldots \ldots \ldots \ldots \ldots \ldots \ldots$. ciliolata

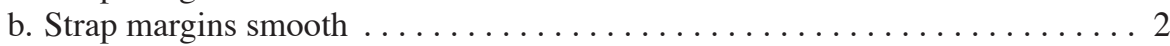

2a. Straps cervicorn, reduced fork normally spur-like and recurved; branching irregularly dichotomous $\ldots \ldots \ldots \ldots \ldots \ldots \ldots \ldots \ldots \ldots \ldots \ldots \ldots \ldots \ldots \ldots$ cervicornis

b. Straps regularly dichotomously branched ................ 3

3a. Straps more than $2 \mathrm{~mm}$ broad . . . . . . . . . D. dichotoma var. dichotoma

b. Straps less than $2 \mathrm{~mm}$ broad ............ D. dichotoma var. intricata

\section{Dictyota cervicornis Kütz.}

Literature - Jaasund, 1976; De Clerck \& Coppejans, 1997; De Clerck, 2003.

Distribution - Eritrea: Massawa, Resi Medri, Gurgussum, Gulf of Zula, Sheik Said Island, Dur-gam Island, Dur-gella Island, Dissei Island, Nokra Island. Red Sea: Egypt. Western Indian Ocean: SWIO, NWIO, Arabian Gulf.

Specimens studied: ER-PH-055, 061-065.

Dictyota ciliolata Sond. ex Kütz.

Literature - Jaasund, 1976; De Clerck, 2003.

Distribution - Eritrea: Bay of Assab, Dissei Island, Shuma Island; Dahlak Archipelago (Lipkin \& Silva, 2002). Red Sea: Egypt, Israel, Yemen. Western Indian Ocean: SWIO, NWIO, Arabian Gulf.

Specimens studied: ER-PH-071-076, 078, 079.

Dictyota dichotoma (Huds.) J. V. Lamour.

Literature - Hörnig \& Schnetter, 1988.

Distribution - Eritrea: Dur-gam Island, Gulf of Zula. Red Sea: Sudan, Egypt, SaudiArabia. Western Indian Ocean: SWIO, NWIO.

Specimen studied: ER-PH-080. 
*Dictyota dichotoma var. intricata (C. Agardh) Grev.

Literature - Hörnig \& Schnetter, 1988; De Clerck, 2003.

Distribution - Eritrea: Dur-gam Island. Red Sea: Sudan, Egypt, Israel, Saudi-Arabia. Western Indian Ocean: SWIO, NWIO, Arabian Gulf.

Specimen studied: ER-PH-081.

\section{LOBOPHORA J. Agardh}

Lobophora variegata (J.V. Lamour.) Womersley ex E.C. Oliveira

Pocockiella variegata (J.V. Lamour.) Papenf.

Literature — Jaasund, 1976; Lawson \& John, 1987.

Distribution - Eritrea: Massawa, Sheik Said Island; Dahlak Archipelago (Lipkin, 1987; Lipkin \& Silva, 2002). Red Sea: Sudan, Egypt, Israel, Yemen. Western Indian Ocean: SWIO, NWIO, Arabian Gulf.

Specimen studied: ER-PH-083.

PADINA Adans.

1a. Thallus distromatic, one belt of hairs alternates with one belt of sporangia ..... P. australis

b. Thallus tristromatic, two belts of hairs alternate with one belt of sporangia. . . . . P. boergesenii

\section{**Padina australis Hauck}

Literature - Verheij \& Prud'homme van Reine, 1993.

Distribution - Eritrea: Sheik Said Island. Western Indian Ocean: NWIO, Arabian Gulf.

Specimen studied: ER-PH-084.

\section{Padina boergesenii Allender \& Kraft}

Literature - Jaasund, 1976; Verheij \& Prud'homme van Reine, 1993.

Distribution - Eritrea: Sheik Said Island (also in Lipkin \& Silva, 2002), Dur-gam Island, Dur-gella Island, Dissei Island, Nokra Island, Gurgussum, Resi Medri, Massawa, Marine Station; Bay of Archico and Dahlak Archipelago (Lipkin \& Silva, 2002). Red Sea: Egypt. Western Indian Ocean: SWIO, NWIO, Arabian Gulf.

Specimens studied: ER-PH-085, 086.

\section{STOECHOSPERMUM Kütz.}

Stoechospermum polypodioides (J.V. Lamour.) J. Agardh

Stoechospermum marginatum (C. Agardh) Kütz. 
Literature - Jaasund, 1976.

Distribution - Eritrea: Assab Bay, Gulf of Zula, Resi Medri, Sheik Said Island, Massawa, Gurgussum; Dahlak Archipelago (Lipkin \& Silva, 2002). Red Sea: Jordan, Israel, Saudi-Arabia, Yemen. Western Indian Ocean: SWIO, NWIO.

Specimens studied: ER-PH-091, 094-097.

\section{FUCALES}

\section{Cystoseira C. Agardh}

1a. Plants bearing numerous terminal vesicles with scattered spines . . . . C. myrica

b. Plants bearing intercalary vesicles with well-spaced spines; vesicles give rise to other vesicles or branches $\ldots \ldots \ldots \ldots \ldots \ldots \ldots \ldots$ Cystoseira spec.

\section{Cystoseira myrica (S.G. Gmel.) C. Agardh - Fig. 5}

Literature - Papenfuss \& Jensen, 1967.

Distribution - Eritrea: Assab Bay, Gurgussum, Marine Station, Resi Medri, Massawa, Mandola Island, Dissei Island, Sheik Said Island, Nokra Island, Dur-gam Island, Dur-gella Island; other parts of the Dahlak Archipelago (Lipkin, 1987; Lipkin \& Silva, 2002). Red Sea: Sudan, Egypt, Jordan, Israel, Saudi-Arabia, Yemen. Western Indian Ocean: SWIO, NWIO, Arabian Gulf.

Specimens studied: ER-PH-051-053.

\section{Cystoseira spec. - Fig. 2-4}

Distribution - Eritrea: Gurgussum.

Note - Cystoseira myrica and C. trinodis (Forssk.) C. Agardh are the only species of the genus reported from the western Indian Ocean. Different ecotypes have been described, ranging from a very large and vesicle-rich northern form to a short and evesiculate southern form (Papenfuss \& Jensen, 1967). The present collection resembles $C$. trinodis in having intercalary vesicles, which can either be determinate or give rise to other vesicles or branches, but differs by well-spaced spines on its vesicles (which is characteristic of $C$. myrica). A specimen of $C$. myrica with intercalary vesicles has been observed in East Africa (Coppejans, pers. com.).

Specimen studied: ER-PH-054.

\section{HORMOPHYSA Kütz.}

Hormophysa cuneiformis (J.F. Gmel.) P.C. Silva

Hormophysa triquetra (C. Agardh) Kütz.

Literature - Jaasund, 1976; Papenfuss, 1968b.

Distribution - Eritrea: Assab Bay, Gurgussum; Dahlak Archipelago (Lipkin \& Silva, 2002). Red Sea: Egypt, Saudi-Arabia. Western Indian Ocean: SWIO, NWIO, Arabian Gulf. 


\section{SARGASSUM C. Agardh}

Many species of Sargassum, some with many varieties and forms, have been reported from the Red Sea, of which 30 are from Eritrea (Papenfuss, 1968a). The majority of these records of Sargassum taxa in the Red Sea are due to Grunow (1915-1916), who described 9 new species and 64 varieties and forms of previously described species. This genus shows marked morphological alterations depending on local environmental differences and age (Lawson \& John, 1987; Kilar et al., 1992). The validity of Grunow's taxa requires a thorough revision. We have had a long struggle and out of the many specimens of Sargassum collected only the following three species could be identified by us; of these, one is new for the area.

1a. Primary axes compressed to flattened . . . . . . . . . . oligocystum

b. Primary branches terete or slightly compressed $\ldots \ldots \ldots \ldots \ldots \ldots \ldots$

2a. Upper leaves lanceolate, smooth to dentate. . . . . . . . . . . S. ilicifolium

b. Upper leaves oblanceolate, dentate to serrate . . . . . . . . S. subrepandum

Sargassum ilicifolium (Turner) C. Agardh

Literature - Trono, 1992; Ateweberhan, 2004.

Distribution - Eritrea: Massawa, Bay of Anfila, Gulf of Zula (winter 2000), Assab Bay, Assarca, Sheik Said Island, Dissei Island, Nokra Island. Western Indian Ocean: SWIO, NWIO.

Specimens studied: ER-PH-S-003, 010, 011-013.

\section{**Sargassum oligocystum Mont.}

Sargassum binderi Sond.

Literature - Jaasund, 1976; Trono, 1992.

Distribution - Eritrea: Gulf of Zula (winter 2000), Massawa, Tewalet, Dissei Island, Dur-gam Island, Sheik Said Island, Nokra Island. Western Indian Ocean: SWIO, NWIO, Arabian Gulf.

Specimens studied: ER-PH-S-002, 007, 009, 014-016.

\section{Sargassum subrepandum (Forssk.) C. Agardh}

Literature - Jaasund, 1976.

Distribution - Eritrea: Bay of Assab, Mandola Island, Adjuz Island, Massawa; Dahlak Archipelago (Lipkin \& Silva, 2002). Red Sea: Sudan, Egypt, Jordan, SaudiArabia. Western Indian Ocean: SWIO, NWIO.

Specimen studied: ER-PH-S-005 (collected in late winter 2000). 
TURBINARIA J. V. Lamour.

1a. Lateral longitudinal ridges of the stalks of the branchlets smooth, intramarginal crown of teeth on the peltate branchlets normally present . . . . . . T. ornata

b. Lateral longitudinal ridges dentate, peltate blades vesiculate . . . . . . . . 2

2a. Peltate branchlets much longer than broad, distal peltate branchlets transverse...

T. decurrens

b. Peltate branchlets not longer than broad, distal peltate branchlets oblique......

T. triquetra

\section{*Turbinaria decurrens Bory}

Literature - Taylor, 1964.

Distribution - Eritrea: Nokra Island. Red Sea: Egypt. Western Indian Ocean: SWIO, NWIO.

Note - The occurrence of Turbinaria decurrens in the Red Sea is denied by Papenfuss (1968a). The present specimens bear blades that are longer than broad, a criterion used to distinguish T. decurrens from T. triquetra (Taylor, 1966).

Specimen studied: ER-PH-100.

**Turbinaria ornata (Turner) J. Agardh

Literature - Taylor, 1964.

Distribution - Eritrea: Dur-gam Island, Nokra Island, Sheik Said Island. Western Indian Ocean: SWIO, NWIO, Arabian Gulf.

Specimen studied: ER-PH-102.

\section{Turbinaria triquetra (J. Agardh) J. Agardh}

Literature - Taylor, 1964.

Distribution - Eritrea: Assab Bay, Resi Medri, Gurgussum, Massawa, Gulf of Zula, Shuma Island, Dissei Island, Entedebir Island, Nokra Island, Sheik Said Island; other parts of the Dahlak Archipelago (Lipkin \& Silva, 2002). Red Sea: Sudan, Egypt, Israel, Jordan, Saudi-Arabia, Yemen. Western Indian Ocean: NWIO.

Note - Turbinaria triquetra is distributed in the Red Sea and on the Djibouti and Somalia coasts of the western Indian Ocean. There are also doubtful records for the Andaman and Nicobar Islands in the Andaman Sea (Silva et al., 1996). In the surroundings of Massawa and the Dahlak Archipelago, this species usually occupies the lower part of the reef flat below the Sargassum zone, where they are the largest plants in the area.

Specimens studied: ER-PH-103, 104. 


\section{CHLOROPHYTA}

\section{KEY TO THE GENERA OF CHLOROPHYTA FROM ERITREA}

1a. Thallus siphonous or with uni- or multiseriate, branched or unbranched filaments

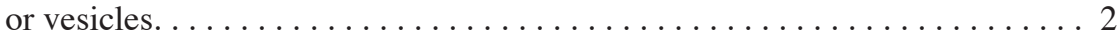

b. Thallus parenchymatous with cell divisions in two or three planes . . . . . 11

2a. Thallus of free uniseriate filaments, branched or unbranched .......... 3

b. Filaments siphonous or multiseriate and then partitioned or interwoven to form a

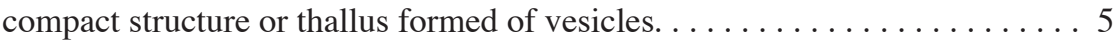

3a. Filaments unbranched except in rhizoids, cells cylindrical, filaments coarse . . . .

Chaetomorpha

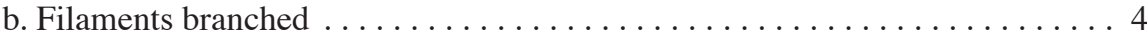

4a. Filaments repeatedly branched, branches similar to the main axes and separated from them by cross walls . . . . . . . . . . . . . . . . . .

b. Filaments less branched, branches often in open connection with the main axes, plants forming firm mats or cushions. . . . . . . . . Cladophoropsis

5a. Thallus composed of large vesicles or of small vesicles and filaments which are

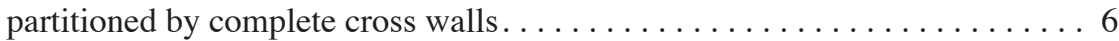

b. With small vesicles and filaments not partitioned by complete cross walls . . 8

6a. Plants gregarious, thallus clavate; vesicles soft, large and elongate Boergesenia

b. Vesicles firm and small, often tightly packed $\ldots \ldots \ldots \ldots \ldots \ldots \ldots$

7a. Thallus solid or hollow, composed of thick walled, rounded or polygonal vesicular cells $500-2000 \mu \mathrm{m}$ diameter. . . . . . . . . . . . . Dictyosphaeria

b. Vesicular cells forming branching segments . . . . . . . . . . Valonia

8a. Plants composed of calcified segments with a filamentous medulla and a cortex of inflated utricles $\ldots \ldots \ldots \ldots \ldots \ldots \ldots \ldots \ldots \ldots \ldots \ldots \ldots \ldots$ Halimeda

b. Thallus siphonous, with or without vesicles, not calcified . . . . . . . . 9

9a. Fan shaped thallus consisting of blades of interwoven, laterally connected and branched filaments and a bulbous base of interwoven rhizoids. . . Avrainvillea

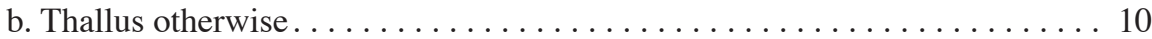

10a. Thallus with pinnately or spirally branched laterals; no trabeculae. . . Bryopsis

b. Thallus consisting of creeping stolons and erect parts, with or without ramuli, internal structure provided with internal ridges (trabeculae) . . . . . Caulerpa

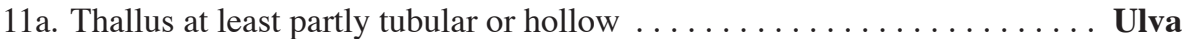

b. Thallus flat, forming mono- or distromatic leafy blades . . . . . . . . 12

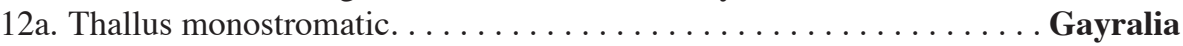

b. Thallus distromatic. ........................ Ulva

\section{ULVALES}

GAYRALIA K.L. Vinogr.

**Gayralia oxysperma (Kütz.) K.L. Vinogr. ex Scagel et al.

Ulvaria oxysperma (Kütz.) Bliding

Monostroma oxyspermum (Kütz.) Doty 
Literature - Burrows, 1990.

Distribution - Eritrea: Nokra Island. Western Indian Ocean: SWIO, NWIO.

Note - Until recently this taxon was reported only from Mauritius (Børgesen, 1940) in the Western Indian Ocean region. Coppejans \& Gallin (1989) have reported on its presence in Kenyan mangroves. The present specimens are about $5 \mathrm{~cm}$ in length while the one reported from Mauritius reaches $15 \mathrm{~cm}$.

Specimen studied: ER-CH-043.

\section{ULVA L.}

Molecular phylogenies of the genera commonly considered as Ulva L. and Enteromorpha Link have provided strong evidence that these genera are not distinct evolutionary entities and should not be recognized as separate genera. We have followed Hayden et al. (2003) and have accepted their proposed new classification and nomenclature.

1a. Thallus forming flat, distromatic leafy blades with many holes ... U. reticulata

b. Thallus at least partly tubular or hollow $\ldots \ldots \ldots \ldots \ldots \ldots \ldots \ldots \ldots \ldots$

2a. Plants branched all over the thallus, with both long branches and smaller spinous branches with broad bases; cells in marked longitudinal rows . . . . U. clathrata

b. Plants unbranched or with branches arising from the basal part . . . . . . . 3

3a. Gregarious plants, simple or occasionally divided basally, cylindrical to intestiniform, gradually tapering downward, cells often in both longitudinal and transverse

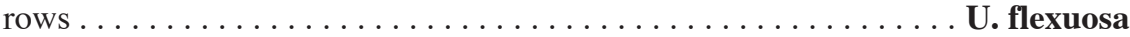

b. Plants solitary or gregarious; thalli more or less compressed; cells unordered. . 4

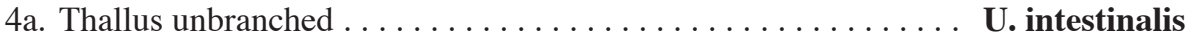

b. Thallus with branches arising from the basal part. . . . . . . U. compressa

**Ulva clathrata (Roth) Grev.

Enteromorpha clathrata (Roth) Grev.

Enteromorpha muscoides (Clemente) Cremades

Enteromorpha ramulosa (Sm.) Carmich.

Literature - Bliding, 1963; Silva et al., 1996.

Distribution - Eritrea: Hirghigo. Western Indian Ocean: SWIO, NWIO, Arabian Gulf.

Note - For conspecifity of Enteromorpha (now Ulva) clathrata and E. muscoides see Blomster et al. (1999), who wrongly considered E. muscoides (based on Ulva muscoides Clemente, 1807) to be the oldest name. However, E. clathrata, based on Conferva clathrata Roth, 1806, clearly has priority.

Specimen studied: ER-CH-037.

\section{Ulva compressa $L$.}

Enteromorpha compressa (L.) Nees

Literature - Bliding, 1963; Koeman, 1985. 
Distribution - Eritrea: Gulf of Zula, Massawa, Hirghigo; Dahlak Archipelago (Lipkin, 1987; Lipkin \& Silva, 2002). Red Sea: Sudan, Egypt, Jordan, Saudi-Arabia, Yemen. Western Indian Ocean: SWIO, NWIO, Arabian Gulf.

Note - Enteromorpha compressa is sometimes considered to be a branched form of E. intestinalis (Bliding, 1963; Burrows, 1990). Recent findings, however, showed genetic differences (Blomster et al., 1997).

Specimen studied: ER-CH-035.

\section{*Ulva flexuosa Wulfen}

Enteromorpha flexuosa (Wulfen) J. Agardh

Literature - Bliding, 1963; Koeman, 1985; Burrows, 1990.

Distribution - Eritrea: Massawa, Marine Station, Hirghigo. Red Sea: Egypt, Israel. Western Indian Ocean: SWIO, NWIO, Arabian Gulf.

Specimens studied: ER-CH-034, 036.

\section{*Ulva intestinalis L.}

Enteromorpha intestinalis (L.) Nees

Literature - Bliding, 1963; Koeman, 1985; Burrows, 1990.

Distribution - Eritrea: Resi Medri, Marine Station, Gurgussum, Massawa; Durgam Island, Dur-gella Island, Nokra Island, Dissei Island, Sheik Said Island. Red Sea: Egypt, Saudi-Arabia. Western Indian Ocean: SWIO, NWIO, Arabian Gulf.

Specimens studied: ER-CH-031-33.

\section{Ulva reticulata Forssk.}

Literature - Jaasund, 1976.

Distribution - Eritrea: Assab Bay, Eddi, Mandola Island, Shuma Island, Massawa, Gurgussum, Sheik Said Island; Dahlak Archipelago (Lipkin \& Silva, 2002). Red Sea: Egypt, Saudi-Arabia, Yemen. Western Indian Ocean: SWIO, NWIO, Arabian Gulf.

Note - For a discussion on Ulva lactuca auct. non see Lipkin \& Silva, 2002.

Specimen studied: ER-CH-042.

\section{CLADOPHORALES}

CHAETOMORPHA Kütz.

Chaetomorpha linum (O.F. Müll.) Kütz.

Chaetomorpha aerea (Dillwyn) Kütz.

Literature - Jaasund, 1976; Burrows, 1990.

Distribution - Eritrea: Assab, Gulf of Anfila, Massawa, Gurgussum, Sheik Said Island; Bay of Archico (Hirghigo) and Dahlak Archipelago (Lipkin \& Silva, 2002). Red Sea: Sudan, Egypt, Jordan. Western Indian Ocean: SWIO, NWIO, Arabian Gulf. 
Note - These algae form loose and thick clumps of bright green filaments. They occur entangled with seaweeds in the intertidal areas. The filaments are unbranched, composed of large, cylindrical and rectangular cells. Attachment and the size of the cells have been considered as the main features of distinction between $C$. linum and C. aerea. According to some field and laboratory experiments attached forms give rise to unattached ones, as a result of which these taxa can be regarded as one species (Christensen, 1957; Burrows, 1990). However, Lipkin \& Silva (2002) treat these taxa as separate species. For discussions see that paper. The present specimens are all unattached but entangled with other algae. The cells are $175-400 \mu \mathrm{m}$ in length and about $175-450 \mu \mathrm{m}$ in width.

Specimens studied: ER-CH-019-021.

\section{ClADOPHORA Kütz.}

1a. Plants growing in shallow lagoons with muddy bottom . . . . . . . . albida

b. Plants usually epiphytic or growing in rocky and sandy pools . . . . . C. koeiei

*Cladophora albida (Nees) Kütz.

Literature - Van den Hoek, 1963.

Distribution - Eritrea: Nokra Island. Red Sea: Egypt, Jordan, Israel. Western Indian Ocean: SWIO.

Specimen studied: ER-CH-023.

\section{*Cladophora koeiei Børgesen}

Literature - Khoja, 1987; De Clerck \& Coppejans, 1996.

Distribution - Eritrea: Sheik Said Island, Dur-gam Island, Gurgussum. Red Sea: Saudi Arabia. Western Indian Ocean: NWIO, Arabian Gulf.

Note - This material is very similar to Cladophora vagabunda (L.) C. Hoek.

Specimens studied: ER-CH-024-026.

\section{SIPHONOCLADALES}

\section{BOERGESENIA Feldmann}

\section{Boergesenia forbesii (Harv.) Feldmann}

Literature - Jaasund, 1976.

Distribution - Eritrea: Sheik Said Island, Gurgussum. Red Sea: Egypt. Western Indian Ocean: SWIO, NWIO.

Note - Boergesenia forbesii forms solitary or gregarious, bright green, shiny, clubshaped thalli filled with liquid. They reach about $4 \mathrm{~cm}$ in length and its vesicles are attached to each other by small rhizoidal holdfasts. They form clumps on rocks and dead corals in tide pools exposed to moderate wave action.

Specimens studied: ER-CH-004, 005. 


\section{CLADOPHOROPSIS Børgesen}

Cladophoropsis herpestica (Mont.) M. Howe

Cladophoropsis javanica (Kütz.) P.C. Silva

Cladophoropsis zollingeri (Kütz.) Reinbold

Literature - Børgesen, 1940-1957.

Distribution - Eritrea: Sheik Said Island, Dur-gam Island, Gurgussum; Dahlak Archipelago: Museri Island (Lipkin \& Silva, 2002). Red Sea: Egypt, Jordan. Western Indian Ocean: NWIO, SWIO, Arabian Gulf.

Note - Plants form firm cushions or mats in places exposed to surf. Branches are formed by lateral growth of cells cut off from the apical cell. These subapical cells stay in open connection with the laterals at least in the upper parts of the axes, with branches tapering towards the apex. Cell diameter 200-300 $\mu \mathrm{m}$. Lipkin \& Silva (2002) discussed the name of this species and they found this alga often intermingled with Cladophoropsis membranacea (Bang ex C. Agardh) Børgesen; the latter species often being dominant. That species has not been found by us.

Specimen studied: ER-CH-027.

\section{DiCTYOSPHAERIA Decne. ex Endl.}

1a. Plants hollow or globular when young, forming a convoluted firm monostromatic layer when old, surface cell 100-3000 $\mu \mathrm{m}$ diameter, no spiny internal outgrowths

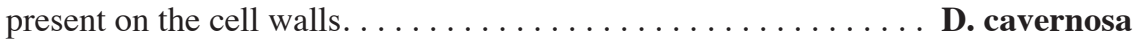

b. Solid, parenchymatous plants, surface cell $500-1000 \mu \mathrm{m}$, cell walls with spiny internal outgrowths $\ldots \ldots \ldots \ldots \ldots \ldots \ldots \ldots \ldots \ldots \ldots \ldots \ldots$ versluysii

\section{Dictyosphaeria cavernosa (Forssk.) Børgesen}

Literature - Jaasund, 1976.

Distribution - Eritrea: Assab Archipelago, Sheik Said Island (also in Lipkin \& Silva, 2002), Dur-gam Island, Gurgussum; other islands in the Dahlak Archipelago (Lipkin, 1987; Lipkin \& Silva, 2002). Red Sea: Sudan, Egypt, Israel, Jordan, Saudi-Arabia. Western Indian Ocean: SWIO, NWIO, Arabian Gulf.

Specimens studied: ER-CH-028, 029A.

\section{**Dictyosphaeria versluysii Weber Bosse}

Literature - Jaasund, 1976.

Distribution - Eritrea: Sheik Said Island, Gurgussum. Western Indian Ocean: SWIO, NWIO.

Specimen studied: ER-CH-029B. 


\section{VALONIA C. Agardh}

1a. No utricles near cross walls, dicho- or polytomous branching always apical; vesicles anastomosing and attached by small circular clusters of hapteroid cells (fibulae) $\ldots \ldots \ldots \ldots \ldots \ldots \ldots \ldots \ldots \ldots \ldots \ldots \ldots \ldots \ldots \ldots \ldots \ldots \ldots$. fastigiata

b. Small cells (utricles) present near cross walls, branching apical or lateral; without fibulae .......................... utricularis

**Valonia fastigiata Harv. ex J. Agardh

Literature - Jaasund, 1976; Sartoni, 1986, 1992.

Distribution - Eritrea: Sheik Said Island. Western Indian Ocean: SWIO, NWIO.

Specimen studied: ER-CH-045.

Valonia utricularis (Roth) C. Agardh

Literature - Børgesen, 1940-1957.

Distribution - Eritrea: Assab Bay, Sheik Said Island. Red Sea: Israel. Western Indian Ocean: SWIO, NWIO, Arabian Gulf.

Specimen studied: ER-CH-044.

\section{BRYOPSIDALES}

AVRAINVILLEA Decne.

Avrainvillea amadelpha (Mont.) A. Gepp \& E. Gepp

Literature - Børgesen, 1940-1957.

Distribution - Eritrea: Massawa, Dur-gam Island, Marine Station. Red Sea: Sudan, Egypt, Jordan. Western Indian Ocean: SWIO, NWIO, Arabian Gulf.

Specimens studied: ER-CH-001, 002.

\section{BRYOPSIS J.V. Lamour.}

Note - All collected plants are much smaller than the dimensions of Bryopsis plumosa (Huds.) C. Agardh in Europe.

1a. Branch arrangement opposite or unilateral, pinnae and pinnules adaxial . ......

B. pennata

b. Branch arrangement radial. . . . . . . . . . . . . . . . . . 2

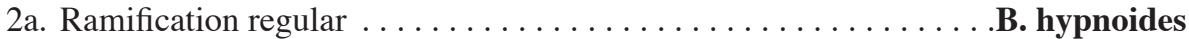

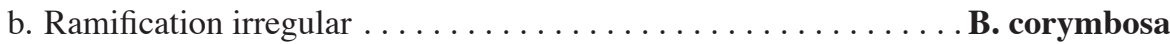


*Bryopsis corymbosa J. Agardh

Literature - Nizamuddin, 1995.

Distribution - Eritrea: Massawa, Marine Station, Nokra Island. Red Sea: Egypt. Western Indian Ocean: SWIO.

Specimen studied: ER-CH-006.

*Bryopsis hypnoides J. V. Lamour.

Literature - Nizamuddin, 1995.

Distribution - Eritrea: Massawa, Marine Station. Red Sea: Egypt, Jordan, SaudiArabia. Western Indian Ocean: SWIO, NWIO, Arabian Gulf.

Specimen studied: ER-CH-008.

**Bryopsis pennata J.V. Lamour.

Literature - Nizamuddin, 1995.

Distribution - Eritrea: Dur-gam Island, Dissei Island. Western Indian Ocean: NWIO. Specimens studied: ER-CH-009-011.

\section{CAULERPA J.V. Lamour.}

1a. Erect branches compressed with spirally twisted serrate margins. . . C. serrulata

b. Erect parts cylindrical and not spirally twisted $\ldots \ldots \ldots \ldots \ldots \ldots \ldots \ldots \ldots$

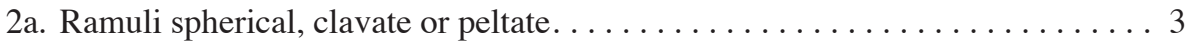

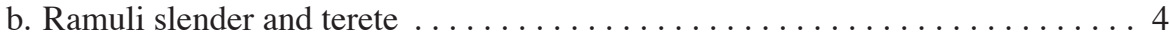

3a. Ramuli peltate, stalk ending into disc-like apex . . . . . C. racemosa var. peltata

b. Ramuli globose, with a short and constricted stalk, densely packed over entire erect part......................... lentillifera

4a. Ramuli slightly acuminate, distichously arranged on axes . . . C. sertularioides

b. Ramuli sharply acuminate, with radial arrangement around the axes... C. selago

\section{Caulerpa lentillifera J. Agardh}

Literature - Jaasund, 1976; Sartoni, 1978; Coppejans \& Beeckman, 1989; Coppejans \& Prud'homme van Reine, 1992.

Distribution - Eritrea: Dur-gam Island. Red Sea: Egypt, Saudi-Arabia. Western Indian Ocean: SWIO, NWIO.

Specimen studied: ER-CH-012.

Caulerpa racemosa (Forssk.) J. Agardh var. peltata (J.V. Lamour.) Eubank

Literature - Taylor, 1967; Coppejans \& Beeckman, 1989; Coppejans \& Prud'homme van Reine, 1992.

Distribution - Eritrea: Nokra Island (also recorded by Lipkin \& Silva (2002) as C. peltata), Dur-gam Island. Red Sea: Sudan, Egypt, Saudi-Arabia. Western Indian Ocean: SWIO, NWIO. 
Note - Many other varieties of Caulerpa racemosa have been described and some have been found in the Dahlak Archipelago (Taylor, 1967; Lipkin, 1987; Lipkin \& Silva, 2002) but these were not found during the field period of the first author.

Specimens studied: ER-CH-013, 014.

Caulerpa selago (Turner) C. Agardh

Literature - Taylor, 1967.

Distribution - Eritrea: Gurgussum, Sheik Said Island. Red Sea: Sudan, SaudiArabia, Yemen. Western Indian Ocean: SWIO, NWIO.

Specimen studied: ER-CH-016.

\section{Caulerpa serrulata (Forssk.) J. Agardh}

Literature - Taylor, 1967; Jaasund, 1976; Sartoni, 1978; Coppejans \& Beeckman, 1990; Coppejans \& Prud'homme van Reine, 1992.

Distribution - Eritrea: Massawa, Resi Medri; Dahlak Archipelago (Lipkin, 1987; Lipkin \& Silva, 2002). Red Sea: Egypt. Western Indian Ocean: SWIO, NWIO.

Specimen studied: ER-CH-017.

\section{Caulerpa sertularioides (S.G. Gmel.) M. Howe}

Literature - Taylor, 1967; Jaasund, 1976; Sartoni, 1978; Coppejans \& Beeckman, 1990; Coppejans \& Prud'homme van Reine, 1992.

Distribution - Eritrea: Massawa; Dahlak Archipelago (Lipkin, 1987; Lipkin \& Silva, 2002). Red Sea: Egypt, Jordan, Saudi-Arabia, Yemen. Western Indian Ocean: SWIO, NWIO.

Specimen studied: ER-CH-018.

\section{HALIMEDA J.V. Lamour.}

Our Halimeda identifications have been checked by W.H.C.F. Kooistra.

1a. Light to moderate calcification, segments arranged in one plane ... H. discoidea

b. Heavily calcified, segments arranged in more than one plane. . . . . . H. opuntia

\section{Halimeda discoidea Decne.}

Literature - Jaasund, 1976; Verheij \& Prud'homme van Reine, 1993.

Distribution - Eritrea: Resi Medri, Gurgussum, Massawa, Sheik Said Island, Durgam Island; other Dahlak islands, amongst which Nokra Island (Lipkin \& Silva, 2002). Red Sea: Sudan, Egypt. Western Indian Ocean: SWIO, NWIO.

Specimens studied: ER-CH-040-042B.

Halimeda opuntia (L.) J.V. Lamour.

Literature - Jaasund, 1976; Verheij \& Prud'homme van Reine, 1993. 
Distribution - Eritrea: Resi Medri, Massawa, Assab Bay, Mandola Island, Dissei Island; other Dahlak islands, amongst which Nokra Island (Lipkin, 1987; Lipkin \& Silva, 2002). Red Sea: Sudan, Egypt, Jordan, Saudi-Arabia. Western Indian Ocean: SWIO, NWIO.

Specimen studied: ER-CH-038.

\section{REFERENCES}

References marked with an asterisk (*) have been used to prepare the database for Table 2 on regional distribution.

Angelucci, A., C.F. Boni, F. Carbone, G. Cancetti, G. Civitelli, L. d'Alessandro, A. Funicello, G.B. la Monica, S. Lombardi, E.L. Palmieri, G. Mariotti, R. Matteucci \& B. Toro. 1982. Il Gulbet entatu nell Arcipellago delle Isole Dahlak (Mar Rosso): Un esempio de sedimentazione carbonatica. Boll. Soc. Paleontol. Ital. 21: 189-200.

*Ateweberhan, M. 1996. Taxonomic and ecological study of benthic marine macroalgae from the Red Sea coasts of Eritrea. MSc thesis. Free University of Brussels.

Ateweberhan, M. 2004. Seasonal dynamics of coral reef algae in the southern Red Sea. PhD thesis. Universiteit Groningen.

Bliding, C. 1963. A critical survey of European taxa in Ulvales I: Capsosiphon, Percursaria, Blidingia, Enteromorpha. Opera Bot. 8, 3:1-160.

Blomster, J., C. A. Maggs \& M. J. Stanhope. 1997. Molecular and morphological analysis of Enteromorpha intestinalis and E. compressa in the British Isles. Phycologia 36, suppl.: 9.

Blomster, J., C.A. Maggs \& M.J. Stanhope. 1999. Extensive intraspecific morphological variation in Enteromorpha muscoides (Chlorophyta) revealed by molecular analysis. J. Phycol. 35: $575-586$.

B $ø$ rgesen, F. 1932. A revision of Forsskål's algae mentioned in Flora Aegyptiaco-Arabica and found in his herbarium in the Botanical Museum of the University of Copenhagen. Dansk. Bot. Ark. 8, 2: 1-64.

*Børgesen, F. 1940-1957. Some marine algae from Mauritius. K. Dansk. Vidensk. Selsk. Biol. Medd. Copenhagen.

Braithwaite, C.J.R. 1987. Geology and palaeography of the Red Sea region. In: A.J. Edwards \& S.M. Head (eds.), Key environments: Red Sea: 22-44. Pergamon Press, Oxford.

Brummitt, R.K. \& C.E. Powell (eds.). 1992. Authors of plant names. Royal Botanic Gardens, Kew.

Burrows, E. 1990. Seaweeds of the British Isles. Vol. II. Chlorophyta. Natural History Museum Publications. London.

Christensen, T. 1957. Chaetomorpha linum in the attached state. Bot. Tidsskr. 53: 311-316.

Clemente y Rubio, S.d.R. 1807. Ensayo sobre las variedas de la vid común que vegetan en Andaluciá. Madrid.

Coppejans, E. 1983. Iconographie d'Algues Méditerranéennes. Biblioth. Phycol. 63: 1-28, 317 plates.

*Coppejans, E. \& H. Beeckman. 1989. Caulerpa section Sedoideae (Chlorophyta, Caulerpales) from the Kenyan coast. Nova Hedwigia 49: 381-393.

*Coppejans, E. \& H. Beeckman. 1990. Caulerpa (Chlorophyta, Caulerpales) from the Kenyan coast. Nova Hedwigia 50: 111-125.

*Coppejans, E. \& F. Gallin. 1989. Macroalgae associated with the mangrove vegetation of Gazi Bay (Kenya). Bull. Soc. Roy. Bot. Belgique 122: 47-60.

*Coppejans, E., F. Leliaert \& O. de Clerck. 2000. Annotated list of new records of marine macroalgae for Kenya and Tanzania, since Isaac's and Jaasund's publications. Biol. Jaarb. 67: 31-93.

Coppejans, E. \& W.F. Prud'homme van Reine. 1992. Seaweeds of the Snellius-II Expedition (E Indonesia): the genus Caulerpa (Chlorophyta-Caulerpales). Bull. Séanc. Acad. R. Sci. OutreMer. 37: 667-712.

De Clerck, O. 2003. The genus Dictyota in the Indian Ocean. Opera Bot. Belg. 13: 1-205. 
*De Clerck, O. \& E. Coppejans. 1994. Status of the macroalgae and seagrass vegetation after the 1991 Gulf war oil spill. Courier Forschungsinst. Senckenberg 166: 18-21.

*De Clerck, O. \& E. Coppejans. 1996. Marine algae of the Jubail Marine Wildlife Sanctuary, Saudi Arabia. In: F. Krupp, A.H. Abuzinada \& I.A. Nader (eds.), A marine wildlife sanctuary for the Arabian Gulf. Environmental research and conservation following the 1991 Gulf war oil spill: 199-289. NCWCD, Riyadh, Saudi Arabia and Senckenberg Research Institute, Frankfurt am Main.

De Clerck, O. \& E. Coppejans. 1997. The genus Dictyota (Dictyotaceae, Phaeophyta) from Indonesia in the herbarium Weber-van Bosse, including the description of Dictyota canaliculata spec. nov. Blumea 42: 407-420.

De Jong, Y.S.D.M., C. Hitipeuw \& W.F. Prud'homme van Reine. 1999. A taxonomic, phylogenetic and biogeographic study of the genus Acanthophora (Rhodomelaceae, Rhodophyceae). Blumea 44: 217-251.

De Toni, J.B. \& G. Paoletti. 1888. Spigolature per la flora di Massawa e di Suakim. Bull. Soc. Veneto-Trentina Sci. Nat. 4: 64-76.

*Ducker, S.C. 1967. The genus Chlorodesmis (Chlorophyta) in the Indo-Pacific region. Nova Hedwigia 13: 145-182.

*Ducker, S.C. 1969. Additions to the genus Chlorodesmis (Chlorophyta). Phycologia 8: 17-20.

Edwards, F.J. 1987. Climate and oceanography of the Red Sea. In: A.J. Edwards \& S.M. Head (eds.), Key environments: Red Sea: 45-70. Pergamon Press, Oxford.

*Farghaly, M.S. 1980. Algues benthiques de la Mer Rouge et du bassin occidental de l'Océan Indien (étude taxonomique et essai de répartition, notamment des Udotéacées). Thèse. Université des Sciences et Techniques du Langedoc, Montpellier.

Forsskål, P. 1775. Flora aegyptiaco arabica ... Copenhagen.

Garbary, D.J. \& J.T. Harper. 1998. A phylogenetic analysis of the Laurencia complex (Rhodomelaceae) of the red algae. Cryptog. Algol. 19: 185-200.

Grunow, A. 1915-1916. Additamenta ad cognitorum Sargassorum. Verh. K. K. Zool.-Bot. Ges. Wien 65: 329-448 (1915) \& 66: 1-48, 136-185 (1916).

Haroun, J. \& W.F. Prud'homme van Reine. 1993. A biogeographical study of Laurencia and Hypnea species of the Macaronesian Region. Courier Forschungsinst. Senckenberg 159: 119-125.

Hatta, A.M. \& W.F. Prud'homme van Reine. 1991. A taxonomic revision of Indonesian Gelidiales (Rhodophyta). Blumea 35: 347-380.

Hayden, H.S., J. Blomster, C. A. Maggs, P.C. Silva, M. J. Stanhope \& R. Waaland. 2003. Linnaeus was right all along: Ulva and Enteromorpha are not distinct genera. Eur. J. Phycol. 38: 277-294.

Head, S.M. 1987. Introduction. In: A.J. Edwards \& S.M. Head (eds.), Key environments: Red Sea: 1-21. Pergamon Press, Oxford.

Hommersand, M.H. 1963. The morphology and classification of some Ceramiaceae and Rhodomelaceae. Univ. Calif. Publ. Bot. 35: 165-366.

Hörnig, I. \& K. Schnetter. 1988. Notes on Dictyota dichotoma, D. menstrualis, D. indica and D. pulchella spec. nova (Phaeophyta). Phyton (Horn) 28: 277-291.

Hoyle, M.D. 1994. Gracilaria dawsonii spec. nov. (Rhodophyta, Gigartinales): A second flattened species from the Hawaiian Islands. In: I.A. Abbott (ed.), Taxonomy of economic seaweeds with reference to some Pacific and Western Atlantic species IV: 85-94. California Sea Grant, La Jolla.

*Jaasund, E. 1976. Intertidal seaweeds in Tanzania: A field guide. University of Troms $\emptyset$.

Keum, Y.-S., J.H. Oak, W.F. Prud'homme van Reine \& I. K. Lee. 2003. Comparative morphology and taxonomy of Sphacelaria species with tribuliform propagules (Sphacelariales, Phaeophyceae). Bot. Mar. 46: 113-124.

*Khoja, T.M. 1987. New records of marine algae for the Red Sea coast of Saudi Arabia. Bot. Mar. 30: $167-176$.

Kilar, J., M. Hanisak \& T. Yoshida. 1992. On the expression of phenotypic variability: Why is Sargassum so taxonomically difficult? In: I. A. Abbott (ed.), Taxonomy of economic seaweeds with reference to some Pacific and Western Atlantic species III: 95-117. California Sea Grant, La Jolla.

Koeman, R. 1985. The taxonomy of Ulva Linnaeus, 1753, and Enteromorpha Link, 1820 (Chlorophyceae) in the Netherlands. PhD thesis. Universiteit Groningen. 
Lawson, G.W. \& D.M. John. 1987. The marine algae and coastal environment of tropical West Africa 2nd ed. Beih. Nova Hedwigia. 93: 1-415.

Licata, G. B. 1882. Alghe della Baia di Assab. La Natura, Milano 1882, 12: 181.

*Lipkin, Y. 1972. Marine algal and sea-grass flora of the Suez Canal. Israel J. Zool. 21: 405-446.

*Lipkin, Y. 1987. Marine vegetation of the Museri and Entedebir Islands (Dahlak Archipelago, Red Sea). Israel J. Bot. 36: 87-99.

*Lipkin, Y. 1991. Life in the littoral of the Red Sea. In: A.C. Mathieson \& P.H. Nienhuis (eds.), Ecosystems of the world 24: Intertidal and littoral ecosystems: 391-427. Elsevier, Amsterdam.

*Lipkin, Y. \& P.C. Silva. 2002. Marine algae and seagrasses of the Dahlak Archipelago, southern Red Sea. Nova Hedwigia 75: 1-90.

Morcos, S.E. 1970. Physical and chemical oceanography of the Red Sea. Oceanogr. Mar. Biol. Ann. Rev. 8: 73-202.

Nam, K.W. 1999. Morphology of Chondrophycus undulata and C. parvipapillata and its implications for the taxonomy of the Laurencia (Ceramiales, Rhodophyta) complex. Eur. J. Phycol. 34: 455-468.

Nizamuddin, M. 1995. Species of the genus Bryopsis Lamouroux (Bryopsidales-ChlorophyceaeChlorophyta) from the Coast of Pakistan. Pakistan J. Bot. 27: 3-39.

Norris, J.N. 1985. Gracilaria and Polycavernosa from the Caribbean and Florida: Key and list of the species of economic potential. In: I.A. Abbott \& J.N. Norris (eds.), Taxonomy of economic seaweeds with reference to some Pacific and Caribbean species I: 101-114. California Sea Grant, La Jolla.

Norris, R.E. 1992. A proposed phylogenetic scheme for the Gelidiales. In: I. A. Abbott (ed.), Taxonomy of economic seaweeds with reference to some Pacific and Western Atlantic species III: 67-79. California Sea Grant, La Jolla.

Pakker, H. 1995. Thermal traits and biogeography of tropical to warm temperate Atlantic seaweeds. $\mathrm{PhD}$ thesis. Universiteit Groningen.

*Papenfuss, G.F. 1968a. A history, catalogue and bibliography of the Red Sea benthic algae. Bull. No. 50. Contributions to the knowledge of the Red Sea, No. 42. Israel J. Bot. 17: 1-118.

*Papenfuss, G.F. 1968b. The history, morphology and taxonomy of Hormophysa (Fucales: Cystoseiraceae). Phytomorphology 17: 42-47.

*Papenfuss, G.F. \& T. Edelstein. 1974. The morphology and taxonomy of the red alga Sarconema (Gigartinales: Solieriaceae). Phycologia 13: 31-43.

*Papenfuss, G. \& J. Jensen. 1967. The morphology, taxonomy and nomenclature of Cystophyllum trinodis (Forsskål) J. Agardh and Cystoseira myrica (S.G. Gmel.) C. Agardh (Fucales: Cystoseiraceae). Blumea 15: 17-24.

Piccone, A. 1884. Contribuzioni all'algologia Eritrea. Nuovo Giorn. Bot. Ital. 16: 281-332.

Piccone, A. 1886. Alghe del viaggio di circumnavigazione della Vettor Pisani. Genova.

Piccone, A. 1889. Manipola di alghe del Mar Rosso. Mem. R. Accad. Lincei. 6: 64-78.

Piccone, A. 1893. Materiali botanici della campagna idrografia dello Scilla nel Mar Rosso. Atti. Soc. Ligust. Sci. Nat. Geogr. 4: 379-382.

Piccone, A. 1900a. Nuove contribuzioni alla flora marina dell Mar Rosso. Atti. Soc. Ligust. Sci. Nat. Geogr. 11: 251-268.

Piccone, A. 1900b. Alghe galleggianti raccolte dal dott. Vincenzo Ragazzi nel Mar Rosso, tra Rahaita ed Assab. Annuario Reale Ist. Bot. Roma 9: 117-118.

Piccone, A. 1900c. Alghe raccolte dall'ing. Luigi Robecchi-Bricchetti nel Mar Rosso e sulla costa dalla Somalia. Annuario Reale Ist. Bot. Roma 9: 119-123.

Rayss, T. 1959. Contribution à la connaissance de la flore marine de la Mer Rouge. Bull. Sea Fish. Res. Sta. Haifa 23: 1-32.

Rayss, T. \& I. Dor. 1963. Nouvelle contribution à la connaissance des algues marines de la Mer Rouge. Bull. Sea Fish. Res. Sta. Haifa 34: 11-42.

Rodríguez, D. \& B. Santelices. 1988. Separation of Gelidium and Pterocladia on vegetative characters. In: I.A. Abbott (ed.), Taxonomy of economic seaweeds with reference to some Pacific and Caribbean species II: 115-125. California Sea Grant, La Jolla.

Roth, A.G. 1806. Catalecta botanica, ... Fasc. 3. Müller, Leipzig.

Santelices, B. 1998. Taxonomic review of the species of Pterocladia (Gelidiales, Rhodophyta). J. Appl. Phycol. 10: 237-252. 
Santelices, B. \& M. Hommersand. 1997. Pterocladiella, a new genus in the Gelidiaceae (Gelidiales, Rhodophyta). Phycologia 36: 114-119.

*Sartoni, G. 1978. Ricerche sulla flora algale della Somalia centro-meridionale 1. Il genere Caulerpa. Webbia 32: 397-416.

*Sartoni, G. 1986. Algal flora and its vertical distribution on the Gesira cliff (central-southern Somalia). Webbia 39: 355-377.

*Sartoni, G. 1992. Research on the marine algae of South-central Somalia 3. The Siphonocladales - Cladophorales complex. Webbia 46: 291-326.

*Scagel, R.F. \& M. Chihara. 1968. A morphological study of the red alga Leveillea jungermannioides. Canad. J. Bot. 46: 1553-1554.

*Schils, T. \& E. Coppejans. 2003. Phytogeography of upwelling areas in the Arabian Sea. J. Biogeogr. 30: 1339-1356.

Shimada, S., T. Horiguchi \& M. Masuda. 2000. Confirmation of the status of three Pterocladia species (Gelidiales, Rhodophyta) described by K. Okamura. Phycologia 39: 10-18.

*Silva, P.C., P.W. Basson \& R.L. Moe. 1996. Catalogue of the benthic marine algae of the Indian Ocean. Univ. Calif. Publ. Bot. 79: 1-1259.

Stewart, J.G. 1968. Morphological variation in Pterocladia pyramidale. J. Phycol. 4: 76-84.

Stewart, J.G. 1992. Separation of California species of Gelidium and Pterocladia: an evaluation of vegetative characters. In: I.A. Abbott (ed.), Taxonomy of economic seaweeds with reference to some Pacific and Western Atlantic species III: 183-191. California Sea Grant, La Jolla.

Taylor, W.R. 1960. Marine algae of the eastern tropical and subtropical coasts of the Americas. Univ. of Michigan.

*Taylor, W.R. 1964. The genus Turbinaria in eastern seas. J. Linn. Soc., Bot. 58: 475-487.

*Taylor, W.R. 1966. Notes on Indo-Pacific Turbinarias. Hydrobiologia 28: 91-100.

*Taylor, W.R. 1967. Caulerpas of the Israel South Red Sea Expedition. Bull. Sea Fish. Res. Sta. Haifa 43: 13-17.

Trono Jr., G.C. 1992. The genus Sargassum in the Philippines. In: I.A. Abbott (ed.), Taxonomy of economic seaweeds with reference to some Pacific and Western Atlantic species III: 43-92. California Sea Grant, La Jolla.

Van den Hoek, C. 1963. Revision of the European species of Cladophora. PhD thesis. Leiden University.

Veldhuis, M.J.W., G.W. Kraay, J.D.L. van Bleijswijk \& M.A. Baars.1997. Seasonal and spatial variability in phytoplankton biomass, productivity and growth in the north-western Indian Ocean: the south-west and north-east monsoon, 1992-1993. Deep Sea Res. 44: 425-449.

Verheij, E. \& W.F. Prud'homme van Reine. 1993. Seaweeds of the Spermonde Archipelago SW Sulawesi, Indonesia. Blumea 37: 385-510.

*Walker, D. 1987. Benthic Algae. In: A.J. Edwards \& S.M. Head (eds.), Key environments: Red Sea: 152-168. Pergamon Press, Oxford.

Weber-van Bosse, A. 1910. Notice sur quelques genres nouveaux d'algues de l'Archipel Malaisien. Ann. Jard. Bot. Buitenzorg 9: 29-30.

Womersley, H.B.S. 1987. The marine benthic flora of southern Australia, Part II. South Australian Government Printing Division, Adelaide.

Wynne, M.J. 1995. Benthic marine algae from the Seychelles collected during the R/V Te Vega Indian Ocean Expedition. Contr. Univ. Michigan Herb. 20: 261-346.

*Wynne, M.J. 2001. New records of benthic marine algae from the Sultanate of Oman, Northern Arabian Sea III. Contr. Univ. Michigan Herb. 23: 389-406.

*Wynne, M.J. \& B.P. Jupp. 1998. The benthic marine algal flora of the Sultanate of Oman: New records. Bot. Mar. 41: 7-14.

Yamada, Y. 1931. Notes on Laurencia, with special reference to the Japanese species. Univ. Calif. Publ. Bot. 16: 185-310.

Zanardini, G. 1851. Algae novae vel minus cognitae in mari Rubro a Portiero collectae. Flora 34: $33-38$.

Zanardini, G. 1858. Plantarum in mari Rubro hucusque collectarum enumeratio (juvante A. Figari). Mem. Reale Ist. Veneto Sci. 7: 209-309. 